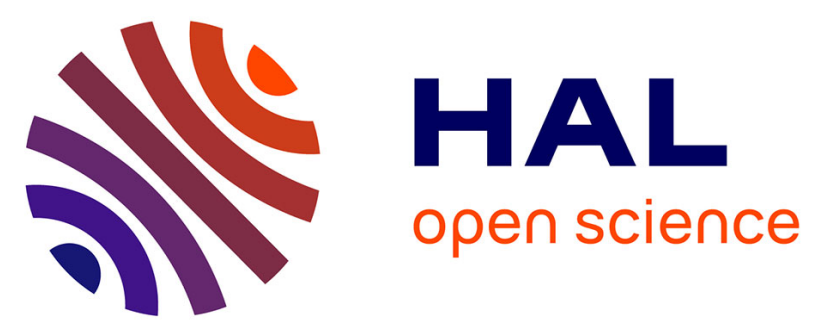

\title{
Benthic control freaks: Effects of the tubiculous amphipod Haploops nirae on the specific diversity and functional structure of benthic communities
}

Carinne Rigolet, Stanislas F. Dubois, Éric Thiébaut

\section{- To cite this version:}

Carinne Rigolet, Stanislas F. Dubois, Éric Thiébaut. Benthic control freaks: Effects of the tubiculous amphipod Haploops nirae on the specific diversity and functional structure of benthic communities. Journal of Sea Research (JSR), 2014, 85, pp.413-427. 10.1016/j.seares.2013.07.013 . hal-01140607

\section{HAL Id: hal-01140607 https: / hal.sorbonne-universite.fr/hal-01140607}

Submitted on 9 Apr 2015

HAL is a multi-disciplinary open access archive for the deposit and dissemination of scientific research documents, whether they are published or not. The documents may come from teaching and research institutions in France or abroad, or from public or private research centers.
L'archive ouverte pluridisciplinaire HAL, est destinée au dépôt et à la diffusion de documents scientifiques de niveau recherche, publiés ou non, émanant des établissements d'enseignement et de recherche français ou étrangers, des laboratoires publics ou privés. 


\title{
Benthic control freaks: Effects of the tubiculous amphipod Haploops
}

\section{nirae on the structural and functional diversity of benthic communities}

Carinne Rigolet $^{\mathrm{a}, \mathrm{b}}$, Stanislas F. Dubois ${ }^{\mathrm{a}}$, Eric Thiébaut ${ }^{\mathrm{b}, \mathrm{c}}$

${ }^{\text {a }}$ IFREMER, DYNECO, Laboratoire Ecologie benthique, Technopole Brest-Iroise, BP70, 29280

Plouzané, France

${ }^{\mathrm{b}}$ CNRS, UMR 7144, Adaptation et Diversité en Milieu Marin, Station Biologique de Roscoff, 29680

Roscoff (France)

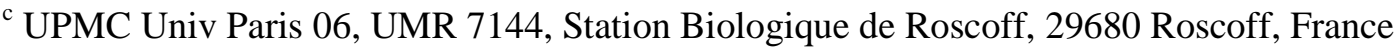

\begin{abstract}
Haploops nirae is a gregarious tubiculous amphipod which extended its habitat over thousands of hectares in shallow waters of South Brittany bays (Bay of Biscay, Atlantic) over the last decades and created uniquely large and dense tube mats. In the bay of Concarneau, we investigated the structural (i.e. species richness and species composition) and functional (i.e. biological traits) diversity of the macrofauna associated with this Haploops community as a comparison with several surrounding softsediment communities to determine the effect of this engineer species on ecosystem functions.

We showed that the occurrence of Haploops tubes and individuals significantly modify sediment features (e.g. change in sediment grain size, increase in $\mathrm{C}$ and $\mathrm{N}$ organic content) but also largely affect species diversity and benthic composition. The species richness is significantly higher but most importantly the species assemblage associated with Haploops habitat is very homogeneous and unique with $33 \%$ of all species exclusively found in this community. We also tested the effect of tube density on species diversity and abundances and the intermediate disturbance hypothesis but we showed
\end{abstract}


surprisingly no significant changes. Multivariate analysis (dbRDA) revealed that Haploops density was by far the factor explaining most of the variation in species composition of benthic communities. A biological trait analysis performed on selected traits revealed that the functional structure of the Haploops community was characterized by a greatly reduced proportion of small to medium long lived, sensitive to disturbance, free living or burrowing/tube-building filter-feeding species. Haploops nirae appears to be a bioengineer and a foundation species that largely modifies its hydro-sedimentary features, controlling diversity and abundances of associated species, and creating a complex set of positive and negative interactions so that a unique benthic assemblage is found in sediments they colonized.

Keywords:

Engineer species

Ampeliscidae tube mats

Macroinfauna diversity

40 Intermediate disturbance hypothesis

Biological trait analysis

Bay of Biscay

\section{Introduction}

Ecosystem engineering is a concept introduced by Jones et al. (1994) who described ecosystem engineers as organisms that cause a biologically mediated habitat modification. By altering biotic or abiotic materials that compose a habitat, these organisms directly or indirectly influence resource availability to other organisms. Ecosystem engineers therefore have the capacity to modify, maintain and/or create habitats for other organisms (Jones et al., 1994; 1997). Many studies have shown that ecosystem engineers affect neighboring organisms and local biodiversity, thus having 
significant impacts throughout the biological community and the entire ecosystem (Stachowicz, 2001; Crooks, 2002).

A large diversity of marine organisms physically engineers marine ecosystems and play key 55 functional roles. Examples include salt marsh plants (e.g. mangroves), seagrasses, reef-forming coral species, mussel beds, burrowing crustaceans, colonial ascidians and burrowing or tubiculous polychaetes (Wright and Jones, 2006; Voultsiadou et al., 2007; Reise et al., 2009). Not only do they physically modify the structure of their habitat (e.g. burrow nets, reef-like bioconstructions, tube mats, rock boring), but they also modify hydro-sedimentary features and ultimately impact ecological processes (nutrient cycling, erosion and sediment stability for example) and associated species (Gutiérrez et al, 2012). In this context, special attention has been given to several tubiculous gregarious polychaete species that increase habitat complexity, modify the sediment dynamics and strongly influence micro- and macro-invertebrate diversity and composition (e.g. Woodin, 1978; 1981; Dubois, 2002; Callaway, 2006). Less is known about other taxonomic groups, especially small tubebuilding crustaceans (but see Mills, 1967).

Ampeliscids are tubiculous amphipods commonly found in shallow environments in temperate and subarctic waters, where they can reach high densities and form dense tube mats (Bellan-Santini and Dauvin, 1988; Dauvin, 1988; Franz and Tanacredi, 1992; Sudo and Azeta, 1996; Göransson, 2002). In those cases, they create a very unique habitat, considerably more complex and heterogeneous than the adjacent homogeneous soft-bottom areas and potentially play significant roles in different ecosystem processes. Many authors revealed that Ampeliscids constitute a major food source for higher-level consumers (Franz and Tanacredi, 1992; Highsmith and Coyle, 1992; Stoner, 2001) and are in some cases major contributors to the highest production levels observed for benthic invertebrate communities (Carrasco and Arcos, 1984; Franz and Tanacredi, 1992). By feeding primarily on phytodetritus, they also greatly influence the pelagic-benthic coupling (Grebmeier and McRoy, 1989). On the other hand, through the tube building and the bioturbation activity, Ampeliscids could be seen as infaunal hydraulic ecosystem engineers that physically modify their habitat by altering the biogeochemistry fluxes and the composition of the surface sediments (Woodin et al., 2010). How large tube mats affect the composition of benthic communities is less investigated. 
The ampeliscid Haploops nirae was first recorded in 1884 in the shallow waters of South

Brittany (France) (Bonnier, 1887). Recent acoustic surveys revealed that this species is spreading and proliferate over large areas of the entire South Brittany coast. For example, the mapping of the bay of Concarneau revealed a 5-fold increase in Haploops nirae habitat surface between 1963 (650 ha in Glémarec, 1969) and 2003 (3680 ha in Ehrhold et al., 2006). Similar patterns were observed for the bay of Vilaine (ca. 7000 ha in 2010) and other muddy coastal environments (unpublished reports). As many gregarious species, Haploops nirae exhibits dense populations, spanning from 6800 to 25500 ind. $\mathrm{m}^{-2}$ (Rigolet et al., 2012). In comparison, densities did not exceeded 5000 ind. $\mathrm{m}^{-2} 25$ years ago (Glémarec et al., 1986). Although the environmental causes of these recent changes remain unknown, the increase in density and the spreading of this engineer species provides a backdrop to investigate the effects of large tubiculous species mats on ecosystems, and especially regarding major changes in communities' structure, on local and regional diversity, and ultimately on the functioning of the ecosystem. While the link between species richness and diversity, and ecosystem functions is still debated in marine ecology (Stachowicz et al., 2007), increasing attention has been paid to investigate the functional diversity in communities (Mouillot et al., 2011) and to develop relevant approaches to assess marine ecosystem functioning. Biological Traits Analysis (BTA) has proven to be a very useful tool for identifying changes in functioning of benthic assemblages exposed to disturbance such as bottom trawling (e.g. Tillin et al., 2006; De Juan et al., 2007) and marine aggregate dredging (e.g. Barrio Frojan et al., 2011). Based on the assumption that functional roles performed by species are determined by the species biological traits (Bremner et al., 2006), BTA utilizes species traits (e.g. life 100 history, morphological and behavioral characteristics) as a proxy for functional roles to determine the occurrence of these traits over assemblages (Bremner, 2008). However, Lepš et al. (2006) pointed out that the functional diversity of a community is dependent on the context of the study because the number of traits selected and their identity depends on the question asked and on which processes being investigated in the study. As a result, ecological functions of structuring species (bioengineers) 105 may be overlooked if irrelevant combinations of traits are used, providing therefore erroneous information about the ecological functioning of the ecosystem studied. 
The present study addresses the question of the effects of a widely dispersed tubiculous gregarious species - namely the Ampeliscid amphipod Haploops nirae - on the structural and functional diversity of soft-bottom muddy communities. We use complementary estimates of diversity and species composition to test whether tube mats enhance or adversely affect local and regional diversity. Amphipod species are sensitive to human activity and the former largest European Haploops habitat has largely decreased in the Øresund area (Baltic Sea), likely because of human developments and resulting eutrophication (Göransson et al., 2002). We discuss here potential consequences of the loss (or conversely further spreading) of dense tubiculous bioturbators on species richness and 115 ecosystem functions.

\section{Materials and methods}

\subsection{Study area}

This study was conducted in the bay of Concarneau, situated in the Northern part of the Bay of Biscay (France) (Fig. 1). This area reflects many coastal embayments in Brittany as it is sheltered by a succession of rocky islets and is characterized by soft-bottom substrates, spanning from muddy to muddy-sand, with a depth ranging from 15 to 35 m (Ménesguen, 1980). The westernmost part (north 125 Mouton islets and Glénan Islands) is composed of muddy sands and sandy muds. The central part of the bay, where currents are strongly reduced, is composed of pure muds supporting a dense population of the tubiculous amphipod Haploops nirae. The western edges of the Haploops habitat are surrounded by patchy muddy sediments (Ehrhold et al., 2006).

\subsection{Sampling strategy and laboratory analyses}

To investigate the effects of Haploops on benthic diversity and species assemblages, we compared the macrofauna associated with Haploops with the adjacent benthic communities. A recent mapping survey of the seabed using geoacoustic approaches and complementary benthic biological 
135 grab samples was conducted in the bay of Concarneau (Ehrhold et al., 2006). Preliminary macrofauna analysis reported 4 benthic communities in the bay: the Sternaspis scutata muddy community, the Amphiura filiformis sandy-mud community, the Owenia fusiformis muddy-sand community and the Haploops muddy community (Fig. 1). Using this map contours, 18 stations were randomly distributed in each of the 4 communities. To investigate the effects of changes in Haploops density on diversity and benthic assemblages, the sampling effort was increased in the Haploops community and 9 stations (among 18 stations) were sampled in this community. Three stations were then distributed in each of the other communities (i.e. the Sternaspis community, the Amphiura community and the Owenia community) (Fig. 1). The 18 stations (3 replicates per station) were sampled during summer time (July 2009) using a $0.1 \mathrm{~m}^{2}$ Van Veen grab. Samples were sieved on a $1 \mathrm{~mm}$ circular mesh-size screen and fixed with a 5\% buffered formalin solution. In the laboratory, samples were rinsed, sorted and the macrofauna was identified to the lowest taxonomic level (i.e. generally the species level) and counted.

To characterize each community, environmental parameters from the sediment were sampled at each station using a Reineck box-corer (2 replicates) to collect undisturbed samples. Chlorophyll $a$, phaeopigments, organic matter concentration $(\mathrm{C}$ and $\mathrm{N})$ and sediment grain size were analyzed from the first $5 \mathrm{~cm}$ layer of sediment. Sediment samples were first frozen at $-20^{\circ} \mathrm{C}$ and then freeze-dried to perform analyses, except for granulometry for which samples were kept at $4^{\circ} \mathrm{C}$ to prevent bias in measurements of silt and clay proportion. Grain size distribution was analyzed using a laser particle analyzer (Malvern Mastersizer 2000). Granulometric parameters (i.e. mean grain size in $\mu \mathrm{m}, \%$ of mud, \% of sand, sorting index, clay:silt ratio) were estimated using the GRADISTAT software (Blott 155 and Pye, 2001). Nitrogen and carbon organic content in sediment were measured with an elemental analyser after acidification with $1 \mathrm{M} \mathrm{HCl}$ to remove inorganic calcium carbonates. Primary producer pigments (i.e. chlorophyll $a$ and phaeopigments) were estimated using the monochromatic technique (Lorenzen, 1967) as described in Aminot and Kérouel (2004).

\subsection{Data analysis}


Community structure. To check for the validity of the a priori grouping stations for each

community, a non-metric multi dimensional scaling (nMDS) combined with a cluster analysis was first used. Analyses were conducted on a Bray-Curtis similarity matrix calculated from logtransformed abundances to downweigh the influence of abundant species. Species that appeared once in the dataset (i.e. occurring in less than $2 \%$ of the samples) were removed from multivariate analyses. According to the role of Haploops as an ecosystem engineer, we assume that Haploops densities correspond primarily to an environmental parameter. Consequently, Haploops individuals were removed from multivariate analyses so that only the associated species were considered. Cluster analyses were performed using the group average linkage method. A similarity profile test was performed to test the null hypothesis that a single set of samples, which are not a priori divided into groups do not differ from each other in the multivariate structure using the SIMPROF routine of the PRIMER 6 software package (Clarke and Gorley, 2006). To conduct this test, an "observed" similarity profile was firstly generated in which all Bray-Curtis similarities between the samples were plotted 175 against their rank. A permutation procedure (based on 1000 permutations) was then used to produce the "mean" similarity profile in which all resemblances in the subset of samples were equally plotted against their rank. The statistical test corresponds to the sum of the absolute distance $(\pi)$ between the "observed" similarity profile and the simulated mean profile. A further 999 simulated profiles were then generated and $\pi$ was computed between each of these and the mean simulated profile, defining therefore the range of likely values under the null hypothesis.

In addition, taxa that contributed the most to the observed differences between communities (expressed as \%) were determined from the Bray-Curtis similarity matrix using the SIMPER procedure of the PRIMER 6 software package (Clarke and Gorley, 2006).

Macrofauna diversity. The macrofauna diversity of the sampled communities as defined from the multivariate analyses, was assessed using indices recommended by Gray (2000) for characterizing local diversity, namely Hill's indices (N0, N1 and N2) (Hill, 1973). As described in Hill (1973), N0 corresponds to the species richness (number of species), N1 = exp (H') where $\mathrm{H}^{\prime}$ is Shannon-Wiener diversity (loge) and N2 $=1 /$ SI, where SI is the Simpson's dominance Index. The N1 
190 index is affected by species situated in the middle of the rank sequence, while the Simpson index used

in the calculation of $\mathrm{N} 2$ addresses the degree of dominance of one or a few very abundant species (Whittaker, 1972). The N1 and N2 indices are two measures of heterogeneity diversity. Haploops individuals were also removed from the dataset so that only the associated fauna was considered. A one-way ANOVA was used to test for significant differences between benthic communities in diversity indices and macrofauna abundances. Normality of data was assessed using the KolmogorovSmirnov test and homogeneity of variance was tested using the Levene test. When significant differences occurred between communities, a pairwise multiple comparison procedure (Holm-Sidak Test) was used. All statistical analyses were performed using the Sigmastat 3.5 software (Systat Software, Inc., CA, USA).

As suggested by Gray (2000), diversity indices can meaningfully be estimated at a larger level than at the sample scale. We therefore also calculated the diversity indices at the whole community scale. Since the number of sampled stations differed between communities, diversity measures such as N0, N1 and N2 were assessed using a bootstrap procedure. This method estimates diversity indices for each community through the use of accumulation curves for randomised samples. Bootstrap calculations (50 randomisations) were performed using the EstimateS Win 8.20 software (Colwell, 2009).

Furthermore, as a measure of beta diversity, the taxonomic similarity between the communities was assessed. According to Whittaker (1960), beta diversity is the extent of change in species composition from one location to another. The Jaccard index of similarity which is commonly 210 used in beta diversity analyses (Nekola and White, 1999; Qian, 2009; Condit et al., 2002) was used as a measure of macrofaunal similarity between the benthic communities sampled. The Jaccard's index (coefficient of community $\mathrm{CC}$ ) is defined as $\mathrm{CC}=\mathrm{Ss} /(\mathrm{Sj}+\mathrm{Sk}-\mathrm{Ss})$, where $\mathrm{Ss}$ is the number of species shared by two samples, $\mathrm{Sj}$ the number in the first sample and $\mathrm{Sk}$ the number in the second sample (Jaccard, 1912; Whittaker, 1972). This index ranges from 0 (no species shared) to 1 meaning that all 215 species are shared by two samples. A low number of shared species between two communities corresponds to a high turnover in species composition between the two communities, reflecting high 
beta diversity. To overcome the problem related to a non-homogeneous sampling effort, we calculated

Linking assemblage species to environmental parameters. A one-way ANOVA was used to determine whether environmental parameters $(\mathrm{Chl} a$, phaeopigments concentration, organic $\mathrm{C}$ and $\mathrm{N}$ concentrations and grain size descriptors) differed between the benthic communities. Normality of data was assessed using the Kolmogorov-Smirnov test and homogeneity of variance was tested using the Levene test. To fulfil conditions of normality and homogeneity of variances, the environmental 225 parameter Mean grain size was log transformed. When significant differences occurred between communities, a pairwise multiple comparison procedure (Holm-Sidak Test) was used. To determine the relationships between environmental variables and macrofauna assemblages, a distance-based redundancy analysis (dbRDA) was performed using the PERMANOVA + software (Anderson et al., 2008). The dbRDA is a method of constrained ordination, which displays the relationships among samples points from a fitted model (Legendre and Anderson, 1999). The DISTLM (distance-based linear modeling) routine of the software was therefore used first to analyze and model the linear relationships between multivariate data (community composition) and predictor variables (environmental variables) (Anderson et al., 2008). The parsimonious model built by the DISTLM routine provides a reduced number of environmental variables that best correlate with macrofauna 235 data. The "Akaike Information Criterion" (AIC) which is a measure of the relative goodness of fit of a statistical model was used to determine this model. The selection procedure used calculates the AIC criterion for all possible models (i.e. combinations of predictor variables) and provides the overall 10 best models that were found using the AIC criterion. The model that achieved the lowest AIC value can be considered as the best of the candidate models. The dbRDA routine was then used to perform 240 an ordination of fitted values from the given model built by the DISTLM routine. Before doing the DISTLM and dbRDA routines, preliminary diagnostics have to be made to avoid multi-collinearity (strong inter-correlations) among predictor (environmental) variables. Thus, when two environmental variables showed strong correlation (i.e. $\mathrm{R}>0.95$ ), one of these two variables was removed from the analysis, since they contain redundant information. Moreover, environmental variables that show a 
245 great deal of skewness (identified by the use of Draftman Plots) were transformed to approach normality. In this way, from the 12 environmental variables submitted to the dbRDA analysis (i.e. Chl $a$, phaeopigments, $\% \mathrm{C}, \% \mathrm{~N}, \mathrm{C}: \mathrm{N}$ ratio, mean grain size, $\%$ Mud, $\%$ Sand, sorting index, clay:silt ratio, water depth and Haploops tube density), only 7 (Chl $a$, phaeopigments, \% $, \mathrm{C}: \mathrm{N}$ ratio, mean grain size (log transformed), water depth and Haploops tube density (fourth root transformed)) were selected to be processed by the DISTLM routine for the dbRDA analysis. It is worth noting that Haploops tubes physically modify their habitat and could be considered a source of disturbance in bare sediment, therefore we chose to consider the density of tubes as an environmental variable.

Biological Traits Analysis (BTA). As suggested by Bremner (2008), the initial stage of traits analysis involves the identification of key aspects of functioning in the ecosystem under consideration and the selection of suitable indicator traits. In this perspective, traits that are functionally important have to be selected to provide a relevant picture of the ecosystem functioning. While morphological characteristics of species are commonly used in BTA analyses (Bremner et al., 2006; Paganelli et al., 2012), such characteristics are strongly related to the taxonomic classification of species and could potentially hamper the functional approach: for example, the body form "laterally compressed" or "vermiform" is usually very close to the composition in amphipods and polychaetes, respectively. To assess the functional diversity associated with each community, we selected 7 biological and ecological traits that reflect ecological processes that we consider functionally important to understand how an ecosystem engineering, bioturbating amphipod may induce changes in the functional characteristics of the ecosystem. We choose to gather information concerning (1) the feeding strategy of the taxa (i.e. trophic group) to provide important information about resource utilisation in each community as well as its availability, (2) the life cycle (i.e. lifespan and adult individual size) because those traits are directly related to the secondary production (Brey, 1990; Cusson and Bourget, 2005) and provide information related to the amount of organic matter and energy produced by the community and (3) the behavior (i.e. type of movement, life mode, bioadvective activity) to provide details on overall activity such as the mode of movement of species and how species occupy their area and contribute to sediment reworking and biogeochemical fluxes at the water-sediment interface. 
Biological traits are listed in Table 1. As suggested by Paganelli et al. (2012), we also included the AMBI Index (AZTI's Marine Biotic Index) as a biological trait, as it classifies the species according to their tolerance to disturbance (Borja and Muxika, 2005). Each trait was then sub-divided into modalities and a fuzzy coding procedure (Chevenet et al., 1994) was used to assign a score to each modality of a trait. The species traits were fuzzy coded on a 0 to 3 scale with " 0 " indicating "no affinity" to " 3 " indicating "high affinity" of the taxon for the modality. This approach avoids the assignment of a taxon to a single category, allows taxa to exhibit modalities to different degrees and incorporates information on intraspecific variability in trait expression. In this way, the fuzzy coding procedure leads to a more precise description of species traits. Biological and ecological information on species were gathered from a variety of literature sources, from general handbooks to specialized papers (i.e. taxonomic guides with descriptions of species). We used the Biological Traits Information Catalogue developed by the Marine Life Information Network (www.marlin.ac.uk/biotic/) as well as 285 the AZTI list for the AMBI Index (Borja and Muxika, 2005 and see also www.azti.es) for complementary information, as well as expert input. In rare cases, no information was found. Similarly to the analysis of benthic assemblages, the Haploops species was removed from the dataset and taxa that were found only once in the samples were not retained for the biological traits analysis; we thus constitute an array of 211 taxa by biological traits with 7 variables (traits) and 30 modalities. This “species by traits" array was ordinated using a Fuzzy coded multiple Correspondence Analysis (FCA) which is well adapted for fuzzy coded table (Chevenet et al., 1994). Before FCA calculation, a fuzzy coded file is processed and computes the frequency of use of each modality per trait so that the sum of values by group of modalities is equal to 1 . If the affinity of a species for a variable (trait) is unknown, it is coded " 0 " for all the modalities. The missing values ( $2 \%$ of cases) were thus replaced by the average profile for the corresponding variable during the computation of the fuzzy coded file. In this way, a species with such a score is not taken into account in the calculation of the column weight (Chevenet et al., 1994). We then constituted clusters of species with similar associations of traits using the output of the Fuzzy Correspondence Analysis (i.e. the scores of taxa on the first four axes of the FCA) using Ward's linkage method (Ward, 1963) on Euclidean distances (Usseglio-Polatera et al., 2000). The two first axes of the FCA explained $27.1 \%$ of the variance, in order to take into account a 
larger amount of explained variance to constitute the clusters we decided to use the first four axes

explaining $43 \%$ of the variance. Functional groups of species with similar associations of traits were identified and plotted on the two first axes of the Fuzzy Correspondence Analysis at the weighted average of their taxa and constituted the reference typology of functional groups (Usseglio-Polatera et al., 2000). For each functional group identified, we generated a biological profile which indicates for each trait the proportion of trait modalities exhibited by the group.

To compare the functional diversity among the benthic communities studied, we calculated (from the log-transformed abundances of species per sampling station) the relative frequency of each functional group in the four communities (i.e. Sternaspis, Amphiura, Owenia and Haploops). To test for significant differences in the relative frequency of functional group between benthic communities, a one-way ANOVA was performed. Normality of data was assessed using the Kolmogorov-Smirnov test and homogeneity of variance was tested using the Levene test. When the conditions of normality and homogeneity of variances were not fulfilled even after data transformation, we used the nonparametric test Kruskal-Wallis Analysis of Variance on Ranks. When significant differences occurred between communities, a pairwise multiple comparison procedure (Holm-Sidak Test) was used. Finally, the relative frequency distribution of functional groups in sampling stations was used to plot stations on the reference typology of functional groups, so that the stations are located at the center of the relative frequency distribution of functional groups (Usseglio-Polatera et al., 2000).

Calculations were performed using the statistical software R 2.11.1 (R Development Core 320 Team, 2008 - www.R-project.org) with the ade4 package (Thioulouse et al., 1997).

\section{Results}

\subsection{Community structure}

325 Hierarchical cluster analysis and SIMPROF test revealed that 4 main clusters, i.e. species assemblages that correspond to communities are grouped at a similarity level of $60 \%$. In agreement with the mapping of the bay of Concarneau, the four communities described a priori (i.e. Sternaspis, 
Amphiura, Owenia and Haploops) are well separated on the nMDS plot (Fig. 2). Except for the

Sternaspis community, each benthic community constituted a separate cluster. One station (CO3) sampled in the Sternaspis community exhibited a species assemblage that shared strong similarity to the species assemblage associated with the Haploops stations. Data revealed that this station actually had a relatively low density of Haploops (2 $000 \pm 930$ ind.m² $)$. In the following diversity analyses, we will therefore consider the Sternaspis community as a group of 2 stations (instead of 3) and exclude station CO3. The nMDS plot also showed that Haploops stations are well discriminated, even though a 335 larger sampling effort was made. Species assemblages associated with Haploops community are very different from surrounded benthic assemblages but also very homogeneous.

Species that contributed the most to the Bray-Curtis dissimilarity between communities are listed in Table 2. In all cases between 7 and 9 species represented ca. $20 \%$ of the dissimilarity between the communities, each species contributing approximately the same to the dissimilarity. Polychaetes Terebellides stroemi, Schistomeringos rudolphii and Mediomastus fragilis typified the fauna associated with Haploops community. Overall, amphipods other than Haploops contributed largely to dissimilarity between communities: Ampelisca species (Ampeliscids tubiculous amphipods) are in part responsible for differences between the Owenia community (where they were abundant) and the surrounding communities (where Ampelisca were relatively scarce). Commensal organisms such as the small bivalve Kurtiella bidentata and the brittle star Amphiura filiformis were found in all communities except in the Haploops community. Moreover, the highest density of the polychaete Maldane glebifex (that lives in a consolidated mud tube) in the Amphiura community is in part responsible for the differences with the Sternaspis and Owenia communities. Finally, the presence of the bivalve Abra alba and the small cirratulid Chaetozone gibber contributed to distinguish the Owenia community from the Sternaspis communtiy.

\subsection{Structural diversity}

Mean values of macrofauna diversity measures and abundances within each community are 355 reported in Table 3. For all tested parameters, overall significant differences between communities 
were observed (ANOVA, $\mathrm{p}<0.05$ ). Total abundance of individuals was the highest in the Amphiura

community and was significantly different from the low abundances reported from the Haploops community (Haploops being excluded). Indeed, the macrofauna abundance associated with Haploops community was estimated at $157 \pm 37$ ind. $0.1 \mathrm{~m}^{-2}$ and was 1.5 to 3 times lower than those reported in the adjacent areas. Owenia and Sternaspis communities exhibited intermediate densities which did not significantly differ from Amphiura and Haploops communities. When the Haploops individuals are included, the abundances in this community are far higher than those from adjacent areas $(\mathrm{p}<0.001$, ANOVA) with a mean density of $1208 \pm 317$ ind. $0.1 \mathrm{~m}^{-2}$. While the number of stations sampled in the Haploops community was the highest (9 stations), a very low standard error in abundances was observed, revealing that the Haploops community is characterized by a high homogeneity in the abundances of associated fauna.

Mean species richness (N0) was higher in the Owenia and Haploops communities compared to the Sternaspis community and the Amphiura community. N1 and N2 indices exhibited the same pattern and indicated significantly lower diversity in Sternaspis and Amphiura than in the two others communities. Haploops community showed the highest value for N1 but no significant differences were reported between the high values of N2 in Owenia and Haploops communities.

At a larger scale (i.e. community scale), cumulated values of N0, N1 and N2 based on 50 randomisation bootstraps revealed that for the same sampling effort, highest species richness and diversity values distinguished the Haploops community from all adjacent areas.

The mean proportion of shared species between two communities assessed with the Jaccard's index spanned from $0.16 \pm 0.03$ to $0.41 \pm 0.04$ (Table 4). Owenia and Haploops communities had a mean of $16 \%$ species in common, while Sternaspis shared $41 \%$ of species with the Amphiura community. With a slight turnover of species from one community to another (Jaccard's index ranging from 0.26 to 0.41 ), Sternaspis, Amphiura and Owenia communities showed a relatively high similarity in species composition. In contrast, lowest values of the Jaccard's index (ranging from 0.16 to 0.21 ) were recorded when the Haploops community was compared with the adjacent areas, implying a high turnover of species and very few species shared. Moreover, on the 274 species recorded in the four benthic communities of the bay of Concarneau during this study, 90 species (i.e. $33 \%$ of the total 
number of species) were exclusively found in the Haploops community. Among these species, some

are consistently found in all samples collected in the Haploops community such as the predatory polychaetes of the family Eunicidae (i.e. Eunice vittata and Nematonereis hebes), Terebellidomorph polychaetes (i.e. Lysippe labiata, Amaeana trilobata, Axionice maculata, Pista cristata and Trichobranchus glacialis), the Maldanid polychaete Praxillella gracilis, the Paraonid polychaete Aricidea sp., some amphipod species such as Leptocheirus pectinatus, Lysianassa insperata and Photis inornatus but also the small brittle star Amphipholis squamata and the large bivalve Polititapes virgineus.

\subsection{Linking species assemblages to environmental parameters}

The comparison of sedimentary features revealed that strong differences occurred between the four studied communities (Table 5). The mud content was overall important but was the lowest in the Owenia community (19\%), and significantly increasing from Sternaspis and Amphiura communities (58\% and $49 \%$ respectively) to the Haploops community (72\%). In good agreement with the mud content, the mean grain size followed the same pattern, with significantly lower values in Haploops stations. All communities significantly differed in organic $\mathrm{N} \%$ and $\mathrm{C} \%$ in sediment. Values were significantly higher in the Haploops area $(\mathrm{N} \%=0.30$ and $\mathrm{C} \%=1.85)$ and lower in the Owenia community $(\mathrm{N} \%=0.07$ and $\mathrm{C} \%=0.47)$ suggesting that organic loads were the highest in the Haploops community. The Haploops area was moreover characterized by the lowest $\mathrm{C}: \mathrm{N}$ ratio, which is a proxy for higher organic matter quality. Finally, while no significant differences in chlorophyll $a$ 405 were evidenced between communities, the highest content of phaeopigments in sediment was reported in the Haploops area.

Environmental variables that best explained the relationships between environmental parameters and macrofauna assemblages were as followed: (1) Haploops density (fourth root transformed), (2) mean grain size (log transformed) and (3) water depth. These three variables composed the parsimonious model which explained a very large part $(70.3 \%)$ of the total variation in species assemblages. The distance-based redundancy analysis (dbRDA) plot is illustrated in Fig. 3. 
The first two axes explained $95.3 \%$ of the fitted variation and $67 \%$ of the total variation. On the dbRDA plot, macrofauna samples modelled by the 3 predictor variables exhibited a " $\mathrm{V}$ " shape, hence suggesting that macrofauna assemblages are divided up according to two gradients. The first gradient was largely driven by Haploops density and to a lesser extent by water depth, which kept Haploops stations separated from Sternaspis, Amphiura and Owenia stations. The second gradient was mainly driven by mean grain size and water depth and discriminated Sternaspis and Amphiura stations from the Owenia stations. Although faunal differences between communities were associated with mean grain size and water depth, the greatest proportion of differences in macrofauna assemblages was explained by the density of Haploops. This variable alone explained $54.1 \%$ of the total variation in macrofauna assemblages, far beyond the \% variation explained by the mean grain size (11.5\%) and the water depth (4.8\%). Considering that Haploops individuals were removed from the species matrix and that only associated species were processed, this approach revealed that Haploops density is the parameter that best explained variations in species assemblages.

Variations in species richness and abundance of macrofauna (Haploops individuals excluded) as a function of Haploops density are plotted in Fig. 4. With a density of Haploops ranging from 920 ind. $\mathrm{m}^{-2}$ to 22000 ind. $\mathrm{m}^{-2}$, the species richness (N0) did not show significant differences (Pearson correlation coefficient, $\mathrm{p}=0.234$ ). Moreover, no significant relationship was found between the abundance of associated macrofauna and Haploops density (Pearson correlation coefficient, $\mathrm{p}=0.232$ ). Similarly, N1 and N2 diversity indices were not affected by an increase in Haploops density (Pearson correlation coefficient, $\mathrm{p}=0.678$ and $\mathrm{p}=0.725$ respectively).

\subsection{Functional diversity}

The first two factorial axes of the fuzzy correspondence analysis (FCA) explained respectively 15.8 and $11.3 \%$ of the total variability in species biological traits (Fig. 5). The correlation ratios issued from this analysis revealed which variables (traits) were best explained by the first two axes of the analysis (Table 6). On the F1 axis of the FCA, the modalities of the variables 'trophic group', 'type of movement', 'habit', 'bioturbation' and 'ecological group (AMBI)' are well separated with 41 to $80 \%$ 
440 of the variance explained. On the F2 axis, the modalities of the variable 'bioturbation' are well

separated with a percentage of explained variance of $48 \%$. The modalities of variables 'life span', 'ecological group (AMBI)' and 'individual size' are less well separated on this axis, but better explained on the F3 and F4 axes.

Overall, the F1 axis of the FCA separated carnivore-omnivore free living organisms from sessile tube or burrow-dwellers organisms (Fig. 5). Positive F1 scores are associated with free living carnivorous species that move by crawling and walking, which create diffusive mixing and bulldozing at the sediment surface. Negative F1 scores were associated with sessile deposit- or filter-feeders, which are tube-dwellers and burrowers. The F2 axis separated crawler and/or burrower species with medium life spans, which are disturbance tolerant and of relatively large size to fixed, swimmer and/or walker species, which are of small size and sensitive to disturbance.

From FCA results, the cluster revealed five groups of taxa that each exhibit similar associations of biological traits (Fig. 6). These five groups are relatively well separated on the F1-F2 factorial plane and each of these groups presents a unique set of biological traits (Fig. 7). The group 1 is composed exclusively of sub-surface deposit-feeders which are mainly burrowers (burrow-dwellers or tubedwellers) and create almost exclusively a translocation of sediment from lower layers to the surface and vice versa (conveyer belt transport). They exhibit short to medium life span, are mainly sensitive or tolerant to disturbance and of a medium to large size. Species that are most representative of the functional group 1 are Maldanid polychaetes such as Maldane glebifex and Euclymene oerstedii but also Orbiniid species such as Orbinia cuvieri and Capitellid species (i.e. Notomastus latericeus and Heteromastus filiformis). The group 2 is composed of burrowing organisms that are mainly depositfeeders and/or filters-feeders in a lesser extent. Organisms from this group live in tube or burrow and create a deposition of particles and a diffusive mixing at the sediment surface. Most species of this group are short-lived species and are of small to medium size; their sensitivity to disturbance varied from sensitive to opportunistic. Species that are most representative of this functional group are small 465 burrowing suspension- and deposit-feeding bivalves (such as Kurtiella bidentata and Abra alba) but also polychaetes such as Ampharete finmarchica and Chaetozone gibber for example. The group 3 is mainly composed of burrowing filter-feeders, living in tubes, burrows or free living. They induced no 
bioturbation nor create a surface deposition or bulldoze the sediment. The species from this group have long lifespan, are of medium size and are mainly sensitive to disturbance. Species typifying this group are the brittle star Amphiura filiformis, large bivalves such as Dosinia lupinus and Polititapes virgineus and sabellid polychaetes. The group 4 is composed of species with diverse trophic guilds, type of movement, habit and mode of bioturbation. All species in this group have a short lifespan, are sensitive to disturbance and of very small size. Its representative species are almost exclusively crustaceans such as amphipods and isopods. Finally, the group 5 is composed exclusively of 475 carnivorous-omnivorous, free living species that mainly move by crawling and create a diffusive mixing at the sediment surface. They are mainly indifferent to disturbance and of small size. Predatory-omnivorous polychaetes constitute almost exclusively this functional group; some scavenger gastropods such as Nassarius incrassatus and Euspira pulchella are also included in this group.

Significant differences between communities were observed in the proportions of the 5 functional groups: the proportion of the group 1 was significantly lower in the Owenia community compared to the Amphiura and Haploops communities ( $<<0.001$, ANOVA). Functional group 2 was significantly greater in the Owenia community, with a higher proportion of short-lived burrowing species $(\mathrm{p}<0.001$, ANOVA). Also, the relative proportion of the functional group 3 significantly differed for all communities ( $\mathrm{p}<0.001$, ANOVA) except between the Amphiura and the Owenia communities. The Sternaspis community showed the highest relative proportion of group 3. The Haploops community is only composed of a small proportion of species from this group. No significant differences in the proportion of the functional group 4 were observed between communities. Finally, group 5 is better represented in the Haploops community as compared to the Amphiura and Owenia communities ( $\mathrm{p}<0.001$, ANOVA on ranks) but did not significantly differ from the Sternaspis community.

Based on the relative frequencies of the 5 functional groups in each sampling station, samples are plotted along with the reference typology of groups on the F1-F2 factorial plane (Fig. 9). The relative positions of stations in this space provide information about the functional structure of the benthic macrofauna communities and the functional resemblance between communities. While the relative grouping of all the stations revealed functional redundancy between the four communities, it is worth 
noting that stations from the Haploops community slightly differed from the others, mainly because of

\section{Discussion}

Dense and extensive tube mats created by the tubiculous ampeliscid Haploops nirae in the bay of Concarneau (South Brittany) were investigated here to determine the effects of a dense bioengineer species on benthic assemblages, from both a structural and a functional perspective. This species is a good candidate because (1) Ampeliscidae is one of the largest amphipod families which may form dense populations (Dauvin and Bellan-Santini, 1996) and is commonly considered to be composed of important bioengineers due to their ability to construct dense tubes mats (MacKenzie et al., 2006), and (2) this species is reportedly spreading over large geographical scales in South Brittany raising questions on the consequences of the proliferation of a native species in coastal embayments.

\subsection{Impact of Haploops nirae on benthic macrofauna community}

Using an extensive spatial sampling approach, this study demonstrated that species assemblages associated with Haploops nirae strongly differed from those in adjacent communities even when removing Haploops nirae individuals from the species matrix. The distance based redundancy analysis (dbRDA) revealed that the environmental parameter mainly responsible for macrofauna differences between the Haploops community and the surrounding communities is actually the density of Haploops: $54 \%$ of the total variation in species assemblages is explained by this variable, well above the percentage of variance explained by factors commonly reported to primarily influence macrofauna distribution, i.e. the mean grain size and the water depth (Ellingsen, 2002). This result highlights that the abundance of Haploops individuals is not the prime reason for the uniqueness of species assemblages in Haploops habitat, but that this engineer species strongly affects and controls the species colonizing this habitat. Through the construction of dense tube mats 
(around 10000 ind. $\mathrm{m}^{-2}$ ) Haploops individuals actively build a physically complex and heterogeneous environment comparatively very different from the adjacent, less heterogeneous substrates. These tube aggregations also affect environmental parameters, by increasing the quantity and quality (low $\mathrm{CN}$ ratio) of the organic matter or by modifying the granulometry of this muddy habitat (see Table 5 for example). Ultimately, Haploops nirae seems to facilitate the settlement and further development of a peculiar macrofauna species assemblage. The consequences of the sole occurrence of Haploops nirae on the structure of benthic communities are well illustrated from the data for the station CO3. This 530 station originally reported as a Sternaspis community-station from an exhaustive mapping of the area (Ehrhold et al., 2006) exhibited small but significant Haploops densities (ca 200 ind. $0.1 \mathrm{~m}^{-2}$ ) which cause sharp changes in associated fauna. It harbored then a species assemblage which is intermediate between both communities even though Haploops individuals were removed from the analyses.

Other dense Ampeliscid habitats shared similarities with Haploops community, especially 535 large Ampelisca abdita community from the North-American coast (Franz and Harris, 1988, Larsen and Gilfillan, 2004). Benthic surveys revealed that the Ampelisca abdita-dominated community in Jamaica bay (New York, USA) was clearly different from the adjacent uncolonized communities (Franz and Harris, 1988). Mills (1967) also showed that colonization of dense aggregations of Ampelisca abdita in the Barnstable Harbor (Massachusetts, USA) was followed by marked changes in the macrofauna. Similarly, engineer species de facto strongly influence associated fauna, as reported for reef-building bivalves aggregating into beds and hardening soft sedimentary systems (Tsuchiya and Nishihira, 1985; Gutiérrez et al, 2012) or seagrass beds stabilizing soft sediment and preventing erosion (Edgar, 1990). A large body of literature also reported that tubiculous polychaete species such as Lanice conchilega and Owenia fusiformis profoundly change associated species assemblages (Somaschini, 1993; Zühlke, 2001; Callaway et al., 2010).

Not only did we demonstrate the uniqueness of species assemblages when the sediment is colonized by Haploops but we also showed that the Haploops community is characterized by a strong homogeneity in species assemblages, as evidenced by the very low variability in spatial changes and the high similarity indices in macrobenthic comparison. Similar results were observed by Castilla et al. 550 (2004) for the mounts formed by the ascidia Pyura praeputialis, which exhibit highly similar species 
assemblages. We can therefore assume that engineered habitat promotes the stability and the

constancy of the community structure. Jones et al. (1997) indicated that in the absence of severe abiotic environmental disturbance, many engineers create very stable conditions for those species that are dependent upon them for habitat. In that perspective, the physical constraints created by tubes likely provides a stable environment for a particular combination of species.

\subsection{Impact of Haploops nirae on species diversity and abundances}

Our results demonstrated a larger cumulated species richness in the Haploops community (i.e. 560130 species) compared to adjacent communities where the total species richness was estimated at 80 , 95 and 103 species respectively for the same sampling effort. Diversity indices (N1 and N2) equally showed that the Haploops community was more diversified than the adjacent communities when Haploops densities are not included. Similar results were found in literature: Larsen and Gilfillan (2004) who used the species richness as indicator of diversity, showed that among 11 benthic stations sampled in the Cobscook bay (Maine, USA), the highest species richness occurred in stations colonized by ampeliscids. Sanders (1958) also reported the greatest species richness in stations dominated by three ampeliscid species in the Buzzards bay (Massachusetts, USA). The vast majority of studies have reported positive effects of biogenic habitat structures on diversity indices, species richness and abundances (Crooks, 2002; Godet et al., 2011). This study is thus in agreement with the 570 general idea that tubes of any taxonomic group increase both the sediment stability and the spatial complexity of the bottom and ultimately promote the diversity and the abundances of the associated species (Young and Rhoads, 1971). But interestingly, we also demonstrated that within the Haploops community, both species richness and diversity indices are not affected by an increase in Haploops tube density. Even at very high tubes densities (i.e. 22000 tubes.m $^{-2}$ ), species diversity levels remain 575 high. Assuming that the occurrence of tube-building species can be considered as a disturbance, this result is not in agreement with the intermediate disturbance hypothesis model which states that species richness is maximized when ecological disturbance is neither too rare nor too frequent. For example, even small densities of tubiculous Terebellids increase local species richness up to a certain point, but 
that richness decreases past an apparent tube density threshold (e.g. Trueblood, 1991; Zühlke, 2001).

Similarly, Dubois et al. (2006) evidenced that only an intermediate covering of the Sabellaria reefs by epibionts (oysters) is correlated with the greatest reef species richness and heterogeneity of diversity index values. Unexpectedly, this investigation showed that the density of Haploops (i.e. the level of disturbance) did not matter, because species richness and other diversity measurements remain unchanged, while consistently supporting unique and homogeneous species assemblages. We are confident that the range of Haploops density (i.e. 920 to 22000 ind. $\mathrm{m}^{-2}$ ) is large enough to encompass areas with a lot of available space and scarce tubes as well as densely colonized areas where bare sediment is no longer visible and where Haploops tubes attach to each other. As pointed out by Stachowicz (2001) in a review of positive interactions in ecological communities, Haploops could be seen as a foundation species offering refuges from predation and a larger trophic niche by creating a new habitat on which numerous species depend, and ultimately increasing species richness compared to the surrounding bare sediment. Positive interactions may then modify the intermediate disturbance hypothesis by broadening the conditions under which higher diversity is maintained. However, we hypothesized here that the modification of the environment (e.g. sediment features, processes at the sediment water interface etc.) with only a very low density of Haploops would generate new stresses so that only a few species could settle and develop in a newly colonized area. Haploops nirae can have then antagonistic effects on local diversity: a stressor at low densities and a foundation species at moderate to very high densities.

The beta diversity is not specifically tied to a spatial scale but refers to the turnover of species between different habitats composing the ecosystem (Colwell, 2009). The analysis of the turnover of 600 species between the four studied communities showed that the community that shared the lowest number of species with the adjacent areas was the Haploops community. While this community adjoined the surrounding communities, very few species are held in common, reflecting high beta diversity and low connectivity. The presence of the Haploops community in the bay of Concarneau seems therefore to bring new species to the ecosystem that would otherwise remain excluded from the 605 bay: a third of all species recorded were exclusively found in the Haploops community. A newly discovered species of amphipod (Photis inornatus sp. nov.) was for example consistently found in the 
Haploops community but not in surrounding muddy environments (Myers et al., 2012). This engineer

species contributes to increase the turnover of species in the bay at a previously unseen level and appears to play a crucial role in term of regional biodiversity.

\subsection{Impact of Haploops nirae on habitat characteristics}

The diversity of organisms and uniqueness of species assemblages recorded within the Haploops habitat can be related to the resources (food or space) available for the macrofauna. The

615 large set of environmental parameters analyzed here showed significant differences between all sampled communities for almost all parameters. The Haploops habitat is characterized by an enriched sediment, as the amount of organic carbon and nitrogen are significantly higher, with the lowest $\mathrm{C}: \mathrm{N}$ ratio, and the highest chlorophyll $a$ and phaeopigment concentrations. As a result, the organic matter is more abundant and of better quality (higher digestibility correlates with lower $\mathrm{C}: \mathrm{N}$ ratio) when the 620 sediment is colonized by Haploops. Tubes commonly alter flow patterns at the sediment-water interface and ultimately affect the flux of sedimented particles (Friedrichs et al., 2009). Reducing interface currents and increasing sedimentation processes both contribute to trap suspended organic matter (phytoplankton and marine snow) but the biological activity of Haploops individuals also need to be considered. By actively filtering the water column with their antennae and producing large quantity of pseudofeces (and feces) (Rigolet et al., 2011), Haploops contribute to enrich the sediment they colonized. In Raritan Bay (New Jersey, USA) where a dense population of Ampelisca abdita was observed (about 24000 ind. $\mathrm{m}^{-2}$ ), McKenzie et al. (2006) reported that the sediment surface of the mud was mostly composed of fecal pellets of $A$. abdita mixed with a relatively small mixture of silt and clay. Likewise, while investigating Ampelisca abdita community in Jamaica bay (New York, USA), Franz and Harris (1988) also showed that \%C in sediment spanning from 0.9 to $4.4 \%$ (i.e. higher than for Haploops community) were greater than in the adjacent uncolonized areas.

Haploops habitat offers hence potentially rich sediment for an abundant macrofauna. Paradoxically, abundances of associated fauna in Haploops habitat are the lowest. This is not in accordance with a common result for similar sediment features where the quantity and quality of 
635 organic matter largely affect the diversity (Wieking and Kroncke, 2005). For example, Grebmeier et

al. (1989) found positive correlations between diversity and sediment total organic carbon, silt and clay content and concluded that low food supply is related to low faunal diversity. However, the space available is probably inversely linked with the quantity of organic matter trapped by tube mats. This factor is then a likely explanation for the limited abundance in associated fauna. Numerous inhabitants of engineered habitats are dependent upon the physical conditions modulated by engineer species, and upon resource flows which they influence but do not directly provide; without the engineers, most of these other organisms would disappear (Jones et al. 1994). Haploops tubes and Haploops biological activity engineer a unique habitat that is suitable for a unique set of species to settle, but the competition for space with this engineer species controls the development of other populations and probably limits their abundances.

\subsection{Impact of Haploops nirae on functional diversity}

Changes in species assemblages are not necessarily linked with changes in ecological 650 functions played by organisms and assessing functional diversity has become of primary importance to fully understand the consequence of changes in benthic assemblages (see for example Bremner, 2008). We investigated whether a complete shift in species assemblages following a colonization of sediment by the amphipod Haploops nirae is ultimately also associated with a change in functional diversity. Analyses of ecosystem functions through biological traits and ecosystem functions revealed that the 655 change in the species richness and benthic composition is much deeper than the change in the functional diversity. Of course, the massive colonization of the sediment by a gregarious suspensionfeeder such as Haploops nirae has led to a massive increase in suspension-feeding organisms but as for the associated fauna, we showed that contrary to the adjacent sandy and muddy communities (i.e. Sternaspis, Amphiura and Owenia), the functional structure of the Haploops community was 660 characterized by a greatly reduced proportion of organisms from the functional group 3. Long-lived, burrower, filter-feeders are therefore proportionally less represented in the Haploops community compared to the adjacent areas. The establishment of Haploops communities thus controls and 
prevents other suspension-feeders - burrowers or other tubiculous species - from colonizing. While competition for food and space is often mentioned as a driving factor to explain variations in sessile suspension-feeding invertebrate assemblages (e.g. Buss, 1979; Lesser, 1992), it has been shown that one suspension-feeding species may completely exclude another species by competition for feeding space. Sanders et al. (1962) indicated that the suspension-feeding bivalve Gemma gemma is taking over the dominant suspension-feeders (such as Mya arenaria) in some stations of Barnstable Harbor (Massachusetts) making up more than $94 \%$ of the individuals of that feeding type, hence explaining 670 why other suspension-feeders are not commonly represented in areas where G. gemma is represented in large numbers. Similarly, one should consider that Haploops could exclude or limit other suspension-feeding species. By contrast, there was a greater proportion of small mobile predators (i.e. functional group 5) in the Haploops community which may directly predate Haploops or other small organisms associated to this habitat.

A marked reduction in the proportion of long-lived burrowing suspension-feeders may have major consequences in benthic functioning as it is well known that such organisms represent an important link in the food chain, contributing to the benthic-pelagic coupling and providing food sources for demersal finfishes (Sköld et al., 1994). Moreover, large and long-lived organisms are commonly considered to be productive organisms since the size and the lifespan are directly related to the secondary production of species (Brey, 1990). They represent therefore an important biomass and provide significant energy transfer to higher trophic levels. This could in turn explain why the secondary production of this Haploops community negatively compares with the production of surrounding muddy communities (i.e. Amphiura and Owenia communities), as estimated in a previous study from the same area (Rigolet et al., 2012).

\subsection{Consequences of further Haploops expansion}

Haploops communities have been reported in a few locations all over the world: the bay of Fundy (Canada) (Wildish and Dickinson, 1982), the East Siberian Sea (Russia) (Gukov, 2011), the 690 Øresund and Kattegat (Sweden) (Göransson, 2002) and the Northumberland coast (Scotland) 
(Buchanan, 1963). Densities of Haploops recorded in South Brittany are the highest reported for the genus Haploops (Rigolet et al, 2012). Unlike the dramatic decline in Haploops densities that occurred in the Øresund during the last 100 years (decreasing from 3500 to 100 ind. $\mathrm{m}^{-2}$ today), along with a drastic shrinking of their distribution area (Göransson, 2002) in response to the alteration of environmental conditions (e.g. eutrophication), it is likely that the Haploops community will continue to expand in the whole Bay of Biscay (Atlantic). The Haploops community occupies a wide area in the Bay of Concarneau (ca. 3600 hectares) which has increased by $400 \%$ since the 1960s (Glémarec, 1969). Complementary acoustic mapping surveys conducted in the EU Marine Strategy Framework Directive revealed that Haploops communities are spreading over larger areas in South Brittany. This investigation addresses a crucial issue related to the spreading of an ecosystem engineer species: Haploops habitat contributes to the seascape diversity and to the overall regional increase in species diversity. If the importance of an ecosystem habitat is linked to the uniqueness of its associated fauna, then Haploops are of primary importance in the seascape of the shallow water of South Brittany in the fight against the loss of biodiversity. However, the strong spatial stability and homogeneity in macrofauna assemblages associated with Haploops habitats could adversely affect the total species diversity in the ecosystem as the connectivity between adjacent habitats and Haploops habitat is low. The expansion of Haploops habitat could then ultimately increase the homogenization in benthic habitats at large scale. Similar results have been reported in different coastal embayments of the Atlantic coasts following the introduction and the proliferation of the invasive slipper limpet 710 Crepidula fornicata. By increasing the sediment heterogeneity, the presence of $C$. fornicata stimulates zoobenthic community diversity and abundance in muddy sediments while its expansion promoted the habitat homogenization (de Montaudoin and Sauriau, 1999). Models of habitat-dependant species-area relationships predict biodiversity losses when biogenic habitats in soft-sediments are homogenized or conversely when they are colonizing an entire ecosystem (Thrush et al., 2006). Franz and Harris 715 (1988) suggested that the permanent loss of one or more superdominants such as Ampelisca abdita in Jamaica bay (New York) coupled with a further reduction in species richness could lead to more unstable benthic associations, in which short-term and random species invasions might dominate the benthic community structure. Our results provide evidence that small densities of Haploops would 
cause a complete change in species assemblages, hence suggesting that Haploops is highly controlling 220 species assemblages and ultimately forcing a one-way succession in its benthic habitat, as many abundant species structuring other adjacent communities (such as Amphiura filiformis and Kurtiella bidentata, or Nucula nitidosa) were not even found in Haploops samples. In that case, even a decrease in Haploops density would not allow other species to take over and somehow balance benthic successional stages.

\section{Acknowledgements}

This work was funded by the Programme National sur l'Environnement Côtier (PNEC) and by the Total Fundation for the Biodiversity and the Sea (10/2 211 201/F). The authors thank X. Caisey and J.

D. Gaffet for technical support, as well as the crew of the R.V. Thalia during the PLOOPS campaigns. We are also grateful to Dr. C.G. Gelpi for commenting upon and editing the English grammar.

\section{References}

Aminot, A., Kérouel, R., 2004. Hydrologie des écosystèmes marins. Paramètres et analyses. Ed. Ifremer. $336 \mathrm{pp}$.

Anderson, M.J., Gorley, R.N., Clarke, K.R., 2008. PERMANOVA + for PRIMER: Guide to Software and Statistical Methods, PRIMER-E, Plymouth.

Barrio Frojan, C.R.S., Cooper, K.M., Bremner, J., Defew E.C., Wan Hussin W.M.R., Paterson D.M., 2011. Assessing the recovery of functional diversity after sustained sediment screening at an aggregate dredging site in the North Sea. Est. Coast. Shelf Sci. 92: 358-366.

Bellan-Santini, D., Dauvin, J.-C., 1988. Eléments de synthèse sur les Ampelisca du nord-est Atlantique. Crustaceana 13, 20-60.

Blott, S.J., Pye, K., 2001. GRADISTAT: a grain size distribution and statistics package for the analysis of unconsolidated sediments. Earth Surf. Process. Landf. 26, 1237-1248.

745 Bonnier, J., 1887. Catalogue des crustacés malacostracés recueillis dans la Baie de Concarneau. Octave Doin, Paris. 190 pp. 
Borja, A., Muxika, I., 2005. Guidelines for the use of AMBI (AZTI's Marine Biotic Index) in the assessment of the benthic ecological quality. Mar. Pollut. Bull. 50, 787-789.

Bremner, J., 2008. Species' traits and ecological functioning in marine conservation and management. J. Exp. Mar. Biol. Ecol. 366, 37-47.

Bremner, J., Rogers, S.I., Frid, C.L.J., 2006. Methods for describing ecological functioning of marine benthic assemblages using biological traits analysis (BTA). Ecol. Indic. 6, 609-622.

Brey, T., 1990. Estimating productivity of macrobenthic invertebrates from biomass and mean individual weight. Meeresforschung/Rep. Mar. Res. 32, 329-343.

Buchanan, J.B., 1963. The Bottom Fauna Communities and Their Sediment Relationships off the Coast of Northumberland. Oikos 14, 154-175.

Buss, L.W., 1979. Bryozoan overgrowth interactions - the interdependence of competition for space and food. Nature 281, 475-477.

Callaway, R., 2006. Tube worms promote community change. Mar. Ecol. Prog. Ser. 308, 1616-1599.

Callaway, R., Desroy, N., Dubois, S., Fournier, J., Frost, M., Godet, L., Hendrick, V.J., Rabaut, M., 2010. Ephemeral Bio-engineers or Reef-building Polychaetes: How Stable are Aggregations of the Tube Worm Lanice conchilega (Pallas, 1766)? Integr. Comp. Biol. 50, 237-250.

Carrasco, F., Arcos, D., 1984. Life history and production of a cold-temperate population of the sublittoral amphipod Ampelisca araucana. Mar. Ecol. Prog. Ser. 14, 245-252.

765 Castilla, J.C., Lagos, N.A., Cerda, M., 2004. Marine ecosystem engineering by the alien ascidian Pyura praeputialis on a mid-intertidal rocky shore. Mar. Ecol. Prog. Ser. 268, 119-130.

Chevenet, F., Dolédec, S., Chessel, D., 1994. A fuzzy coding approach for the analysis of long-term ecological data. Freshw. Biol. 31, 295-309.

Clarke, K.R., Gorley, R.N., 2006. PRIMER v6: User Manual/Tutorial, PRIMER-E, Plymouth.

Colwell, R.K., 2009. Statistical estimation of species richness and shared species from samples, Version 8.2. User's Guide and application published at: http://purl.oclc.org/estimates.

Condit, R., Pitman, N., Leigh, E.G., Chave, J., Terborgh, J., Foster, R.B., Núñez, P., Aguilar, S., Valencia, R., Villa, G., Muller-Landau, H.C., Losos, E., Hubbell, S.P., 2002. Beta-Diversity in Tropical Forest Trees. Science 295, 666-669. 
775 Crooks, J.A., 2002. Characterizing ecosystem-level consequences of biological invasions: the role of ecosystem engineers. Oikos 97, 153-166.

Cusson, M., Bourget, E., 2005. Global patterns of macroinvertebrate production in marine benthic habitats. Mar. Ecol. Prog. Ser. 297, 1-14.

Dauvin, J.-C., 1988. Biologie, dynamique, et production de populations de crustacés amphipodes de la Manche occidentale. I: Ampelisca tenuicornis Liljeborg. J. Exp. Mar. Biol. Ecol. 118, 55-84.

Dauvin, J.-C., Bellan-Santini, D., 1996. Ampeliscidae (Amphipoda) from the Bay of Biscay. J. Crustac. Biol. 16, 149-168.

De Juan, S., Thrush, S.F., Demestre, M., 2007. Functional changes as indicators of trawling disturbance on a benthic community located in a fishing ground (NW Mediterranean Sea). Mar. Ecol. Prog. Ser. 334, 117-129.

De Montaudouin, X., Sauriau, P.G., 1999. The proliferating Gastropoda Crepidula fornicata may stimulate macrozoobenthic diversity. J. Mar. Biol. Ass. UK 79, 1069-1077.

Dubois, S., Commito, J.A., Olivier, F., Retière, C., 2006. Effects of epibionts on Sabellaria alveolata (L.) biogenic reefs and their associated fauna in the Bay of Mont Saint-Michel. Est. Coast. Shelf Sci. $68,635-646$.

Dubois, S., Retière, C., Olivier, F., 2002. Biodiversity associated with Sabellaria alveolata (Polychaeta: Sabellariidae) reefs: effects of human disturbances. J. Mar. Biol. Ass. UK 82, 817826.

Edgar, G.J., 1990. The influence of plant structure on the species richness, biomass and secondary production of macrofaunal assemblages associated with Western Australian seagrass beds. J. Exp. Mar. Biol. Ecol. 137, 215-240.

Ehrhold, A., Hamon, D., Guillaumont, B., 2006. The REBENT monitoring network, a spatially integrated, acoustic approach to surveying nearshore macrobenthic habitats: application to the Bay of Concarneau (South Brittany, France). ICES J. Mar. Sci. 63, 1604-1615.

800 Ellingsen, K.E., 2002. Soft-sediment benthic biodiversity on the continental shelf in relation to environmental variability. Mar. Ecol. Prog. Ser. 232, 15-27.

Franz, D.R., Harris, W.H., 1988. Seasonal and spatial variability in macrobenthos communities in 
Jamaica Bay, New York, an urban estuary. Estuaries 11, 15-28.

Franz, D.R., Tanacredi, J.T., 1992. Secondary production of the amphipod Ampelisca abdita Mills and its importance in the diet of juvenile winter flounder (Pleuronectes americanus) in Jamaica Bay, New York. Estuaries 15, 193-203.

Friedrichs, M., Leipe, T., Peine, F., Graf, G., 2009. Impact of macrozoobenthic structures on near-bed sediment fluxes. J. Mar. Syst. 75, 336-347.

Glémarec, M., 1969. . Les peuplements benthiques du plateau continental Nord-Gascogne. PhD thesis Faculty of Sciences Paris, 167 pp.

Glémarec, M., Le Bris, H., Le Guellec, C., 1986. Modifications des écosystèmes des vasières côtières du sud-Bretagne. Hydrobiologia 142, 159-170.

Godet, L., Fournier, J., Jaffré, M., Desroy, N., 2011. Influence of stability and fragmentation of a worm-reef on benthic macrofauna. Est. Coast. Shelf Sci. 92, 472-479.

Göransson, P., 2002. Petersen's benthic macrofauna stations revisited in the Öresund area (southern Sweden) and species composition in the 1990s - signs of decreased biological variation. Sarsia 87, $263-280$.

Gray, J.S., 2000. The measurement of marine species diversity, with an application to the benthic fauna of the Norwegian continental shelf. J. Exp. Mar. Bio. Ecol. 250, 23-49.

Grebmeier, J.M., Feder, H.M., McRoy, C.P., 1989. Pelagic-benthic coupling on the shelf of the northern Bering and Chukchi Seas. II. Benthic community structure. Mar. Ecol. Prog. Ser. 51, $253-$ 268.

Grebmeier, J.M., McRoy, C.P., 1989. Pelagic-benthic coupling on the shelf of the northern Bering and Chukchi Seas. III. Benthic food supply and carbon cycling. Mar. Ecol. Prog. Ser. 53, 79-91.

Gukov, A.Y., 2011. Monitoring of the Bottom Biocenoses of the Novosibirsk Polynya. Oceanology $51,443-448$.

Gutiérrez, J.L., Jones, C.G., Byers, J.E., Arkema, K.K., Berkenbusch, K., Commito, J.A., Duarte, C.M., Hacker, S.D., Lambrinos, J.G., Hendriks, I.E., Hogarth, P.J., Palomo, M.G., Wild, C., 2011. 7.04 - Physical Ecosystem Engineers and the Functioning of Estuaries and Coasts, in: Editors-inChief: Eric Wolanski, Donald McLusky (Eds.), Treatise on Estuarine and Coastal Science. 
Academic Press, Waltham, pp. 53-81.

Highsmith, R.C., Coyle, K.O., 1992. Productivity of arctic amphipods relative to gray whale energy requirements. Mar. Ecol. Prog. Ser. 83, 141-150.

Hill, M.O., 1973. Diversity and evenness: a unifying notation and its consequences. Ecology 54, 427432.

Jaccard, P., 1912. The distribution of the flora in the alpine zone. New Phytol. 11, 37-50.

Jones, C.G., Lawton, J.H., Shachak, M., 1994. Organisms as Ecosystem Engineers. Oikos 69, 373386.

Jones, C.G., Lawton, J.H., Shachak, M., 1997. Positive and Negative Effects of Organisms as Physical Ecosystem Engineers. Ecology 78, 1946-1957.

Larsen, P.F., Gilfillan, E.S., 2004. A Preliminary Survey of the Subtidal Macrobenthic Invertebrates of Cobscook Bay, Maine. Northeast. Nat. 11, 243-260.

Legendre, P., Anderson, J., 1999. Distance-based redundancy analysis: Testing multispecies responses in multifactorial ecological experiments. Ecol. Monogr. 69, 1-24.

Lepš, J., De Bello, F., Lavorel, S., Berman, S., 2006. Quantifying and interpreting functional diversity of natural communities: practical considerations matter. Preslia 78, 481-501.

Lesser, M.P., Shumway, S.E., Cucci, T., Smith, J., 1992. Impact of fouling organisms on mussel rope culture: interspecific competition for food among suspension-feeding invertebrates. J. Exp. Mar. Biol. Ecol. 165, 91-102.

Lorenzen, C.J., 1967. Determination of chlorophyll and phaeopigment spectrophotometric equations. Limnol. Oceanogr. 12, 343-346.

MacKenzie, C.L., Jr., Pikanowski, R., McMillan, D.G., 2006. Ampelisca amphipod tube mats may enhance abundance of northern quahogs Mercenaria mercenaria in muddy sediments. J. Shellfish Res. 25, 841-847.

855 Ménesguen, A., 1980. La macrofaune benthique de la baie de Concarneau: peuplements, dynamique de populations, prédation exercée par les poissons. $\mathrm{PhD}$ thesis University of Western Brittany. 127 pp.

Mills, E.L., 1967. The biology of an ampeliscid crustacean sibling species pair. J. Fish. Res. Board 
Can. 24, 305-355. 860

Mouillot, D., Villéger, S., Scherer-Lorenzen, M., Mason, N.W.H., 2011. Functional Structure of Biological Communities Predicts Ecosystem Multifunctionality. PLos One 6, e17476.

Myers, A., Rigolet, C., Thiébaut, E., Dubois, S.F., 2012. A new species of amphipod, Photis inornatus sp. nov. (Corophiidea, Photidae) from a "Haploops community" in Brittany. Zootaxa 3236, 55-61.

Nekola, J.C., White, P.S., 1999. The distance decay of similarity in biogeography and ecology. J. Biogeogr. 26, 867-878.

Paganelli, D., Marchini, A., Occhipinti-Ambrogi, A., 2012. Functional structure of marine benthic assemblages using Biological Traits Analysis (BTA): A study along the Emilia-Romagna coastline (Italy, North-West Adriatic Sea). Est. Coast. Shelf Sci. 96, 245-256.

Qian, H., 2009. Global comparisons of beta diversity among mammals, birds, reptiles, and amphibians across spatial scales and taxonomic ranks. J. Syst. Evol. 47, 509-514.

Reise, K., Bouma, T., Olenin, S., Ysebaert, T., 2009. Coastal habitat engineers and the biodiversity in marine sediments. Helgoland Mar. Res. 63, 1-2.

Rigolet, C., Dubois, S.F., Droual, G., Caisey, X., Thiébaut, E., 2012. Life history and secondary production of the amphipod Haploops nirae (Kaim-Malka, 1976) in the Bay of Concarneau (South 875 Brittany). Est. Coast. Shelf Sci.113, 259-271.

Rigolet, C., Le Souchu, P., Caisey, X., Dubois, S.F., 2011. Group sweeping: Feeding activity and filtration rate in the tubiculous amphipod Haploops nirae (Kaim-Malka, 1976). J. Exp. Mar. Biol. Ecol. 406, 29-37.

Sanders, H., 1958. Benthic studies in Buzzards Bay. I. Animal-sediment relationships. Limnol. Oceanogr. 3, 245-258.

Sanders, H.L., Goudsmit, E.M., Mills, E.L., Hampson, G.E., 1962. A Study of the Intertidal Fauna of Barnstable Harbor, Massachusetts. Limnol. Oceanogr. 7, 63-79.

Sköld, M., Loo, L.O., Rosenberg, R., 1994. Production, dynamics and demography of an Amphiura filiformis population. Mar. Ecol. Prog. Ser. 103, 81-90.

885 Somaschini, A., 1993. A Mediterranean fine-sand polychaete community and the effect oft he tubedwelling Owenia fusiformis (Delle Chiaje) on community structure. Int. Rev. Gesamten 
Hydrobiol., 78, 219-233.

Stachowicz, J.J., 2001. Mutualism, Facilitation, and the Structure of Ecological Communities. BioScience 51, 235-246.

890 Stachowicz, J.J., Bruno, J.F., Duffy J.E., 2007. Understanding the effects of marine biodiversity on communities and ecosystems. Annu. Rev. Ecol. Syst., 38: 739-766.

Stoner, A.W., Manderson, J.P., Pessutti, J.P., 2001. Spatially explicit analysis of estuarine habitat for juvenile winter flounder: combining generalized additive models and geographic information systems. Mar. Ecol. Prog. Ser. 213, 253-271.

895 Sudo, H., Azeta, M., 1996. Life history and production of the amphipod Byblis japonicus Dahl (Gammaridea: Ampeliscidae) in a warm temperate zone habitat, Shijiki Bay, Japan. J. Exp. Mar. Biol. Ecol. 198, 203-222.

Thioulouse, J., Chessel, D., Dolédec, S., Olivier, J.-M., 1997. “ADE-4: a multivariate analysis and graphical display software”. Stat. Comput. 7, 75-83.

900 Thrush, S.F., Gray, J.S., Hewitt, J.E., Ugland, K.I., 2006. Predicting the effects of habitat homogenization on marine biodiversity. Ecol. Appl. 16, 1636-1642.

Tillin, H., Hiddink, J., Jennings, S., Kaiser, M., 2006. Chronic bottom trawling alters the functional composition of benthic invertebrate communities on a sea-basin scale. Mar. Ecol. Prog. Ser. 318, $31-45$.

905 Trueblood, D.D., 1991. Spatial and temporal effects of terebellid polychaete tubes on soft-bottom community structure in Phosphorescent Bay, Puerto Rico. J. Exp. Mar. Biol. Ecol. 149, 139-159.

Tsuchiya, M., Nishihira, M., 1985. Islands of Mytilus as a habitat for small intertidal animals: effect of island size on community structure. Deep-Sea Res. Oceanogr., B 25, 71-81.

Usseglio-Polatera, P., Bournaud, M., Richoux, P., Tachet, H., 2000. Biological and ecological traits of benthic freshwater macroinvertebrates: relationships and definition of group with similar traits. Freshw. Biol. 43, 175-205.

Voultsiadou, E., Pyrounaki, M.-M., Chintiroglou, C.H., 2007. The habitat engineering tunicate Microcosmus sabatieri (Roule, 1885) and its associated peracarid epifauna. Est. Coast. Shelf Sci. 74, 197-204. 
915 Ward, J.H., 1963. Hierarchical Grouping to Optimize an Objective Function. J. Amer. Statist. Assoc. $58,236-244$.

Whittaker, R.H., 1960. Vegetation of the Siskiyou Mountains, Oregon and California. Ecol. Monogr. 30, 279-338.

Whittaker, R.H., 1972. Evolution and Measurement of Species Diversity. Taxon 21, 213-251.

920 Wieking, G., Kroncke, I., 2005. Is benthic trophic structure affected by food quality? The Dogger Bank example. Mar. Biol. 146, 387-400.

Wildish, D.J., Dickinson, J.J., 1982. A new species of Haploops (Amphipoda, Ampeliscidae) from the Bay of Fundy. Can. J. Zool. 60, 962-967.

Woodin, S.A., 1978. Refuges, Disturbance, and Community Structure: A Marine Soft-Bottom Example. Ecology 59, 274-284.

Woodin, S.A., 1981. Disturbance and Community Structure in a Shallow Water Sand Flat. Ecology $62,1052-1066$

Woodin, S.A., Wethey, D.S., Volkenborn, N., 2010. Infaunal Hydraulic Ecosystem Engineers: Cast of Characters and Impacts. Integr. Comp. Biol. 50, 176-187.

Wright, J.P., Jones, C.G., 2006. The concept of organisms as ecosystem engineers ten years on: progress, limitations and challenges. BioScience 56, 203-209.

Young, D.K., Rhoads, D.C., 1971. Animal-sediment relations in Cape Cod Bay, Massachusetts. I. A transect study. Mar. Biol. 11, 242-254.

Zühlke, R., 2001. Polychaete tubes create ephemeral community patterns: Lanice conchilega (Pallas, 1766) associations studied over six years. J. Sea Res. 46, 261-272. 


\section{Figure captions}

Fig.1. Spatial distribution of the four sampled benthic communities (i.e. Owenia fusiformis, Amphiura filiformis, Sternaspis scutata and Haploops nirae communities) in the bay of Concarneau (South Brittany, Bay of Biscay). Sampling stations (3 reps per stations) are indicated by a black triangle. The map was issued from a benthic survey conducted in 2003 (Ehrhold et al., 2006).

Fig.2. Non-metric multidimensional scaling (nMDS) plot of the benthic macrofauna of the Sternaspis, Amphiura, Owenia and Haploops communities. The groupings (grey circles) resulted from the SIMPROF test and significantly differs from each other. The community symbols are related to benthic communities defined a priori on the basis of the study investigated in 2003 by Ehrhold et al. (2006). Note that the station CO3 a priori belonging to the Sternaspis community significantly differs.

Fig.3. dbRDA ordination of macrofauna community composition as predicted by the DISTLM model. It shows the relationship between environmental predictors that best explain the variation in macrofauna composition in the four communities studied. Note that Haploops individuals were removed from the species matrix and that Haploops density was used as a factor (see data analyses section). Symbols represent macrofauna samples and vectors represent environmental variables included in the parsimonious model. The length of the vector is related to the effect induced by the environmental variable on species assemblages. Note that symbols are related to benthic communities a priori defined on the basis of the study investigated in 2003 by Ehrhold et al. (2006).

965 Fig.4. Relationship between species richness (N0) or macrofauna abundances (Haploops individuals excluded) and Haploops density (ranging from 920 to 22000 ind.m²) in the bay of Concarneau. Note that the same pattern applied for other diversity indices (N1 and N2). 
Fig.5. Ordination of taxa and biological traits by Fuzzy Correspondence Analysis. a) Histogram of eigenvalues. b) Distribution of taxa (solid circles) on the 2 first factorial plane of the Fuzzy Correspondence Analysis. c) Distribution of the modalities of the 7 biological traits on the 2 first factorial plane of the analysis. Each modality was located at the weighted average of taxa positions that are presenting this modality.

Fig.6. Reference typology of groups of similar traits on the F1-F2 factorial plane of Figure 5.

975 Functional groups (open squares) were positioned at the weighted average of their taxa (solid circles). Lines correspond to the link of the mean location of each group to its taxa (solid circles). Dendrogram which results from the clustering analysis processed on the FCA results. The vertical line indicated the partitioning level selected to define groups of similar association of biological traits.

980 Fig.7. Mean biological profiles of the 5 groups of similar traits showing for the 7 traits the proportion of trait modalities exhibited by each group. Numbers at the top of the graphic corresponded to the labels of the functional groups.

Fig.8. Relative frequency distribution of the five groups of similar traits in the four benthic communities (i.e. Sternaspis, Amphiura, Owenia and Haploops) of the Bay of Concarneau.

Fig.9. Relative positions of sampling stations in relation to the reference typology of groups with similar traits. Functional groups are represented by open squares with numbers inside the open squares corresponding to the labels of the functional groups. Stations are located at the weighted average of its 990 group frequency distribution. 


\section{Table 1}

Biological traits and modalities of species selected for the biological traits analysis.

\begin{tabular}{|c|c|c|c|}
\hline No. & Traits & No. & Modalities \\
\hline \multirow[t]{4}{*}{1} & Trophic group & 1 & Filter feeder \\
\hline & & 2 & Carnivore-omnivore \\
\hline & & 3 & Surface deposit feeder \\
\hline & & 4 & Sub-surface deposit feeder \\
\hline \multirow[t]{5}{*}{2} & Type of movement & 1 & Swimmer \\
\hline & & 2 & Burrower \\
\hline & & 3 & Crawler \\
\hline & & 4 & Walker \\
\hline & & 5 & None \\
\hline \multirow[t]{3}{*}{3} & Habit & 1 & Tube dwelling \\
\hline & & 2 & Burrow dwelling \\
\hline & & 3 & Free living \\
\hline \multirow[t]{5}{*}{4} & Bioturbation & 1 & Diffusive mixing \\
\hline & & 2 & Surface deposition \\
\hline & & 3 & Conveyer belt transport \\
\hline & & 4 & No bioturbation \\
\hline & & 5 & Buldozing \\
\hline \multirow[t]{3}{*}{5} & Life span & 1 & Short $(<2$ years $)$ \\
\hline & & 2 & Medium (2-5 years) \\
\hline & & 3 & Long ( $>5$ years) \\
\hline \multirow[t]{5}{*}{6} & Ecological group (AMBI) & 1 & Sensitive (I) \\
\hline & & 2 & Indifferent (II) \\
\hline & & 3 & Tollerant (III) \\
\hline & & 4 & Second-order opportunistic (IV) \\
\hline & & 5 & First order opportunistic (V) \\
\hline \multirow[t]{5}{*}{7} & Individual size & 1 & Very small $(<1 \mathrm{~cm})$ \\
\hline & & 2 & Small $(1-2 \mathrm{~cm})$ \\
\hline & & 3 & Small-medium $(3-10 \mathrm{~cm})$ \\
\hline & & 4 & Medium $(11-20 \mathrm{~cm})$ \\
\hline & & 5 & Medium-large $(21-50 \mathrm{~cm})$ \\
\hline
\end{tabular}


Table 2

Main species contributing to the dissimilarity between sampled communities (cut-off 20\%):

\begin{tabular}{|c|c|c|c|c|c|}
\hline \multicolumn{2}{|c|}{$\begin{array}{l}\text { Community pairwise } \\
\text { comparisons }\end{array}$} & Species & $\begin{array}{l}\text { Average abundance } \\
\text { in } 1^{\text {st }} \text { community } \\
\left(\text { ind } / 0.1 \mathrm{~m}^{2}\right)\end{array}$ & $\begin{array}{l}\text { Average abundance } \\
\text { in } 2^{\text {nd }} \text { community } \\
\left(\text { ind } / 0.1 \mathrm{~m}^{2}\right)\end{array}$ & $\begin{array}{c}\text { Cumulative } \\
\text { contribution } \\
(\%)\end{array}$ \\
\hline \multirow{7}{*}{ Sternaspis } & Amphiura & Maxmuelleria lankesteri & 0 & 4 & 3.34 \\
\hline & & Maldane glebifex & 4 & 22 & 6.67 \\
\hline & & Labidoplax digitata & 4 & 0 & 9.93 \\
\hline & & Ampelisca typica & 0 & 3 & 13.04 \\
\hline & & Abra alba & 1 & 6 & 15.86 \\
\hline & & Ampelisca tenuicornis & 0 & 2 & 18.25 \\
\hline & & Phoronis spp. & 0 & 3 & 20.42 \\
\hline \multirow[t]{8}{*}{ Sternaspis } & Owenia & Abra alba & 1 & 22 & 3.10 \\
\hline & & Chaetozone gibber & 0 & 11 & 6.00 \\
\hline & & Ampelisca spinifer & 0 & 8 & 8.78 \\
\hline & & Ampelisca brevicornis & 0 & 9 & 11.47 \\
\hline & & Labioleanira yhleni & 7 & 0 & 14.07 \\
\hline & & Ampelisca tenuicornis & 0 & 7 & 16.59 \\
\hline & & Spio decoratus & 0 & 6 & 19.07 \\
\hline & & Ampelisca spinipes & 1 & 11 & 21.37 \\
\hline \multirow[t]{7}{*}{ Amphiura } & Owenia & Maldane glebifex & 22 & 0 & 4.45 \\
\hline & & Ampelisca brevicornis & 0 & 9 & 7.41 \\
\hline & & Kurtiella bidentata & 218 & 31 & 10.26 \\
\hline & & Spio decoratus & 0 & 6 & 12.91 \\
\hline & & Ampelisca spinifer & 1 & 8 & 15.43 \\
\hline & & Maxmuelleria lankesteri & 4 & 0 & 17.78 \\
\hline & & Photis longicaudata & 6 & 1 & 20 \\
\hline \multirow[t]{7}{*}{ Sternaspis } & Haploops & Kurtiella bidentata & 97 & 0 & 4.86 \\
\hline & & Amphiura filiformis & 26 & 0 & 8.6 \\
\hline & & Nucula nitidosa & 20 & 0 & 12.01 \\
\hline & & Terebellides stroemi & 0 & 12 & 14.94 \\
\hline & & Mediomastus fragilis & 0 & 7 & 17.23 \\
\hline & & Labioleanira yhleni & 7 & 0 & 19.51 \\
\hline & & Schistomeringos rudolphii & 0 & 8 & 21.78 \\
\hline \multirow[t]{7}{*}{ Amphiura } & Haploops & Kurtiella bidentata & 218 & 0 & 5.23 \\
\hline & & Amphiura filiformis & 46 & 0 & 9.16 \\
\hline & & Terebellides stroemi & 0 & 12 & 11.52 \\
\hline & & Nucula nitidosa & 8 & 0 & 13.77 \\
\hline & & Schistomeringos rudolphii & 0 & 8 & 15.97 \\
\hline & & Pholoe inornata & 8 & 0 & 17.98 \\
\hline & & Mediomastus fragilis & 0 & 7 & 19.96 \\
\hline \multirow[t]{9}{*}{ Owenia } & Haploops & Amphiura filiformis & 26 & 0 & 2.75 \\
\hline & & Kurtiella bidentata & 31 & 0 & 5.38 \\
\hline & & Abra alba & 22 & 0 & 7.96 \\
\hline & & Terebellides stroemi & 0 & 12 & 10.14 \\
\hline & & Pholoe inornata & 15 & 0 & 12.24 \\
\hline & & Chaetozone gibber & 11 & 0 & 14.19 \\
\hline & & Ampelisca brevicornis & 9 & 0 & 16.1 \\
\hline & & Ampelisca spinifer & 8 & 0 & 17.96 \\
\hline & & Schistomeringos rudolphii & 0 & 8 & 19.77 \\
\hline
\end{tabular}




\section{Table 3}

Mean values ( \pm standard errors) of abundance, N0 (species richness), N1 (exp (H')), N2 (1/SI) (at station and community scales) within the 4 communities studied (Sternaspis, Amphiura, Owenia and Haploops). Note that because of different number of stations, diversity indices at the community scale were assessed using a bootstrap approach. Significant differences $(\mathrm{p}<0.05)$ are in bold and post-hoc results of ANOVA are reported as superscript letters. Haploops were removed from the macrofauna data set of all benthic communities to achieve calculations of diversity indices.

\begin{tabular}{|c|c|c|c|c|c|c|c|c|c|}
\hline & \multicolumn{5}{|c|}{ STATION Diversity } & \multicolumn{4}{|c|}{ COMMUNITY diversity } \\
\hline & $\begin{array}{l}\text { Number } \\
\text { of } \\
\text { stations }\end{array}$ & $\begin{array}{c}\text { Abundances } \\
\left(0.1 \mathrm{~m}^{-2}\right)\end{array}$ & No & N1 & $\mathrm{N} 2$ & $\begin{array}{c}\text { Total } \\
\text { species } \\
\text { richness }\end{array}$ & No & N1 & $\mathrm{N} 2$ \\
\hline Sternaspis & 2 & $235 \pm 108^{a b}$ & $59 \pm 9^{a}$ & $11.5 \pm 6.0^{\mathrm{a}}$ & $4.8 \pm 2.2^{\mathrm{a}}$ & 84 & $80 \pm 9^{\mathrm{a}}$ & $10.4 \pm 2.4^{\mathrm{a}}$ & $4.2 \pm 1.2^{\mathrm{a}}$ \\
\hline Amphiura & 3 & $466 \pm 272^{\mathrm{a}}$ & $74 \pm 3^{\mathrm{ab}}$ & $9.6 \pm 5.4^{\mathrm{a}}$ & $3.7 \pm 1.9^{\mathrm{a}}$ & 113 & $95 \pm 13^{b}$ & $7.2 \pm 2.3^{\mathrm{a}}$ & $2.8 \pm 0.8^{\mathrm{a}}$ \\
\hline Owenia & 3 & $279 \pm 102^{\mathrm{ab}}$ & $80 \pm 7^{\mathrm{b}}$ & $31.9 \pm 7.1^{\mathrm{b}}$ & $19.4 \pm 7.2^{b}$ & 119 & $103 \pm 10^{b}$ & $31.7 \pm 3.2^{b}$ & $18.1 \pm 2.9^{b}$ \\
\hline Haploops & 9 & $157 \pm 37^{b}$ & $85 \pm 9^{\mathrm{b}}$ & $43.2 \pm 6.0^{\mathrm{c}}$ & $26.4 \pm 3.8^{b}$ & 183 & $130 \pm 9^{c}$ & $51.1 \pm 4.0^{\mathrm{c}}$ & $32.0 \pm 3.4^{\mathrm{c}}$ \\
\hline p-value & & $p=0.016$ & $\mathrm{p}=\mathbf{0 . 0 0 6}$ & $\mathrm{p}<0.001$ & $\mathrm{p}<0.001$ & & $\mathrm{p}<0.001$ & $\mathbf{p}<0.001$ & $\mathrm{p}<0.001$ \\
\hline
\end{tabular}




\section{Table 4}

Jaccard's index (mean values \pm standard error) of the four communities pairwise comparisons (i.e.

Sternaspis, Amphiura, Owenia and Haploops).

Community pairwise comparisons

Sternaspis

Sternaspis

Amphiura

Sternaspis

Amphiura

Owenia
Number of comparisons

Amphiura

Owenia

Owenia

Haploops

Haploops

Haploops

6

6

9

18

27

27
Mean Jaccard's index

$0.410 \pm 0.038$

$0.260 \pm 0.015$

$0.352 \pm 0.033$

$0.182 \pm 0.022$

$0.209 \pm 0.025$

$0.159 \pm 0.027$ 


\section{Table 5}

Mean values ( \pm standard errors) for sediment characteristics between the benthic communities of the bay of Concarneau (Sternaspis, Amphiura, Owenia and Haploops). Significant differences ( $<<0.05)$ are in bold and post-hoc results of one-way ANOVA are reported with superscript letters

\begin{tabular}{lccccc}
\hline & Sternaspis & Amphiura & Owenia & Haploops & p-value \\
\hline Mud \% & $58.3 \pm 1.2^{\mathrm{b}}$ & $49.3 \pm 4.7^{\mathrm{b}}$ & $18.6 \pm 0.9^{\mathrm{a}}$ & $72.4 \pm 5.8^{\mathrm{c}}$ & $\mathbf{P}<\mathbf{0 . 0 0 1}$ \\
Mean grain size $(\mu \mathrm{m})$ & $34 \pm 1^{\mathrm{b}}$ & $39 \pm 5^{\mathrm{b}}$ & $152 \pm 17^{\mathrm{a}}$ & $23 \pm 4^{\mathrm{c}}$ & $\mathbf{P}<\mathbf{0 . 0 0 1}$ \\
$\mathrm{N} \%$ & $0.22 \pm 0.03^{\mathrm{c}}$ & $0.13 \pm 0.02^{\mathrm{b}}$ & $0.07 \pm 0.01^{\mathrm{a}}$ & $0.30 \pm 0.03^{\mathrm{d}}$ & $\mathbf{P}<\mathbf{0 . 0 0 1}$ \\
$\mathrm{C} \%$ & $1.48 \pm 0.14^{\mathrm{c}}$ & $0.92 \pm 0.02^{\mathrm{b}}$ & $0.47 \pm 0.04^{\mathrm{a}}$ & $1.85 \pm 0.16^{\mathrm{d}}$ & $\mathbf{P}<\mathbf{0 . 0 0 1}$ \\
$\mathrm{C}: \mathrm{N}$ ratio & $6.9 \pm 0.2^{\mathrm{a}}$ & $7.1 \pm 0.8^{\mathrm{a}}$ & $7.2 \pm 1.2^{\mathrm{a}}$ & $6.1 \pm 0.2^{\mathrm{b}}$ & $\mathbf{P}=\mathbf{0 . 0 1 0}$ \\
Chlorophyll $a(\mu \mathrm{g} / \mathrm{g}$ sediment $)$ & $0.72 \pm 0.41^{-}$ & $0.46 \pm 0.23$ & $0.13 \pm 0.22$ & $1.35 \pm 0.81$ & $\mathrm{P}=0.061$ \\
Pheopigments $a(\mu \mathrm{g} / \mathrm{g}$ sediment $)$ & $18.19 \pm 0.76^{\mathrm{a}}$ & $13.07 \pm 1.91^{\mathrm{a}}$ & $10.82 \pm 1.14^{\mathrm{a}}$ & $27.51 \pm 4.29^{\mathrm{b}}$ & $\mathbf{P}<\mathbf{0 . 0 0 1}$
\end{tabular}




\section{Table 6}

Correlation ratios of each biological trait with axes F1 and F2 of the FCA.

\begin{tabular}{lcc}
\hline & $\mathrm{F} 1$ & $\mathrm{~F} 2$ \\
\hline Trophic group & $\mathbf{0 . 8 0 4}$ & 0.319 \\
Type of movement & $\mathbf{0 . 4 0 7}$ & 0.236 \\
Habit & $\mathbf{0 . 6 2 9}$ & 0.009 \\
Bioturbation & $\mathbf{0 . 4 7 3}$ & $\mathbf{0 . 4 8 4}$ \\
Life span & 0.001 & 0.316 \\
Ecological group (AMBI) & $\mathbf{0 . 4 6 4}$ & 0.298 \\
Individual size & 0.038 & 0.351 \\
\hline
\end{tabular}




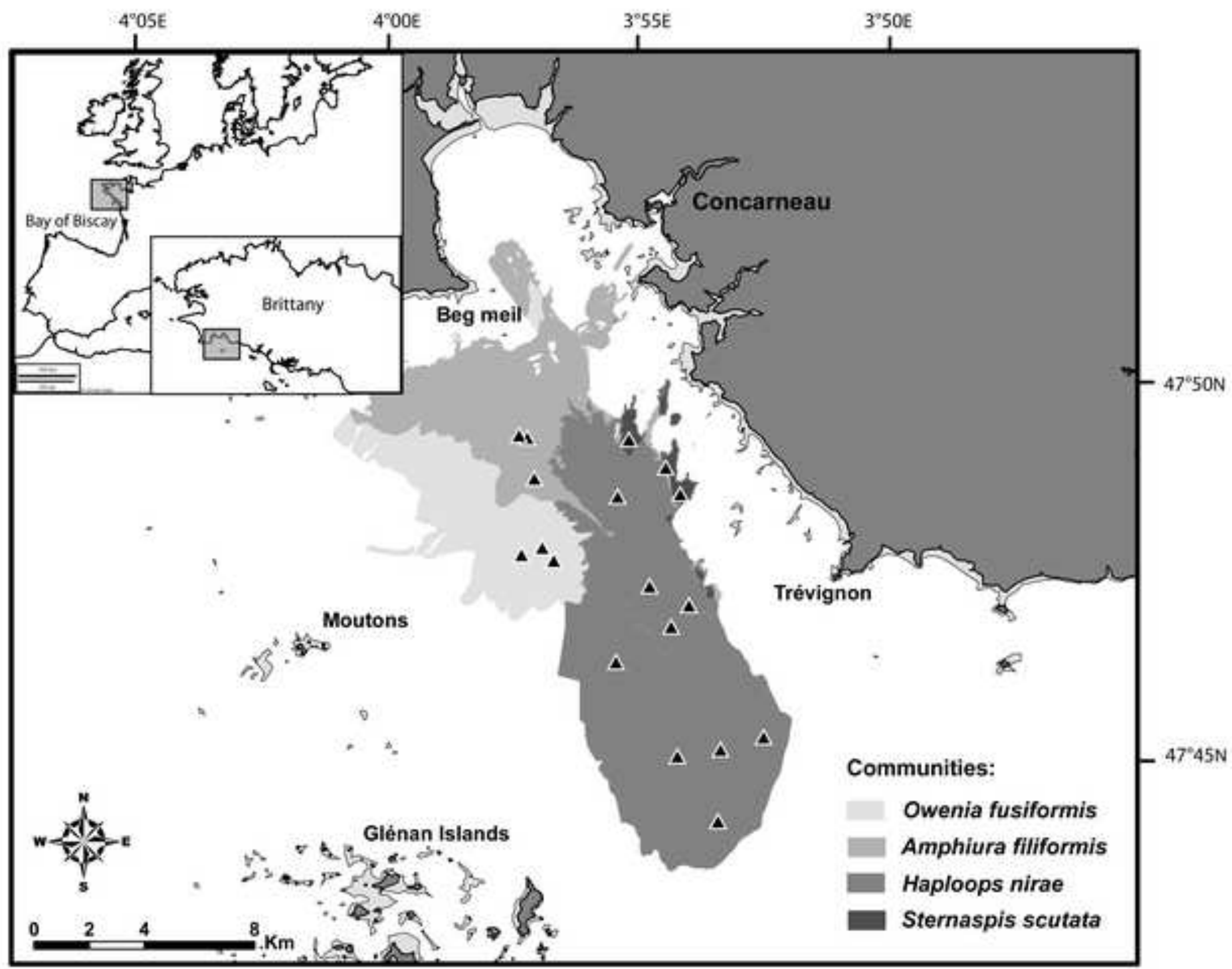


Click here to download high resolution image

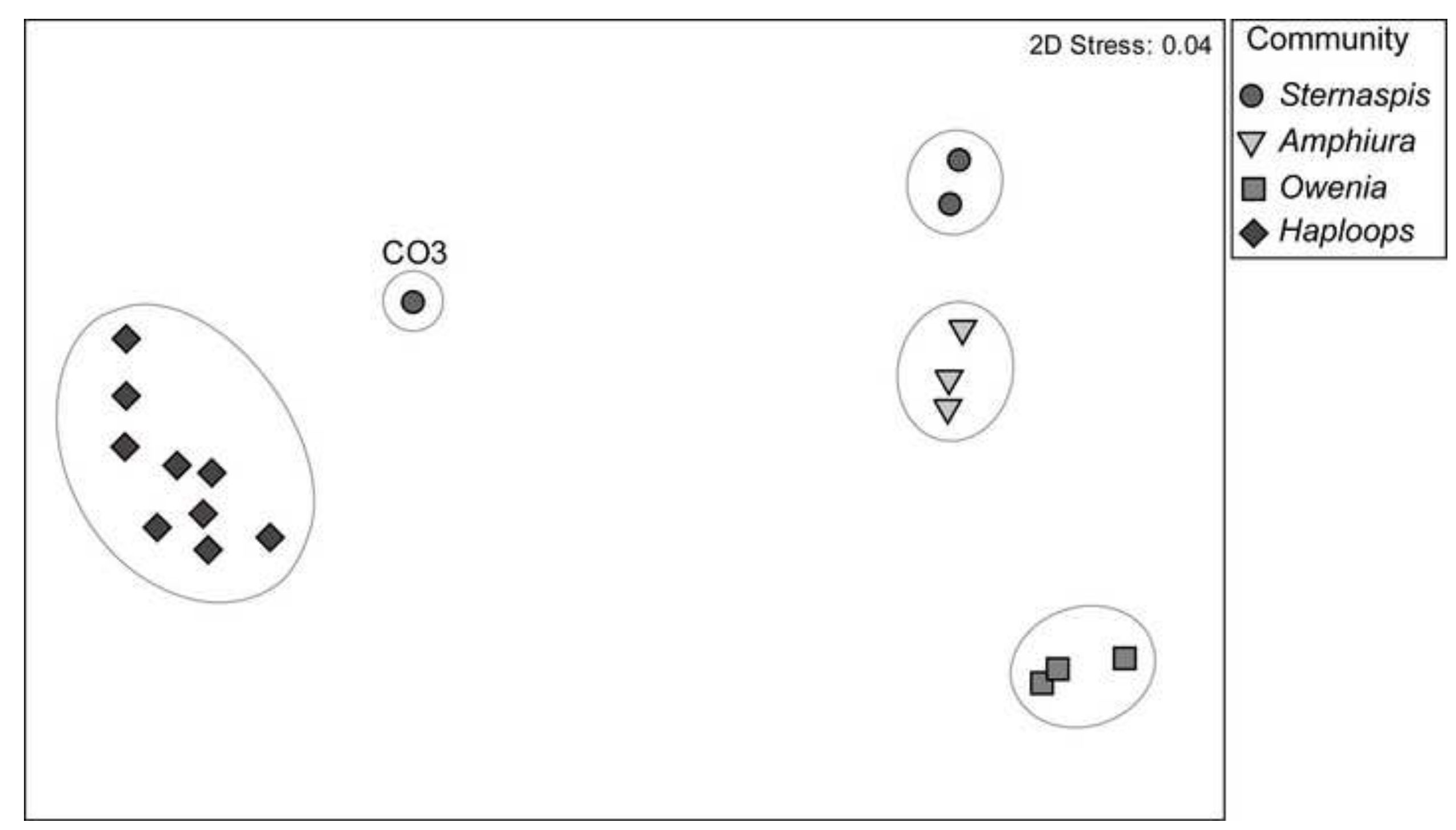

\begin{tabular}{|l|}
\hline Community \\
$\nabla$ Sternaspis \\
$\nabla$ Amphiura \\
$\square$ Owenia \\
Haploops \\
\hline
\end{tabular}




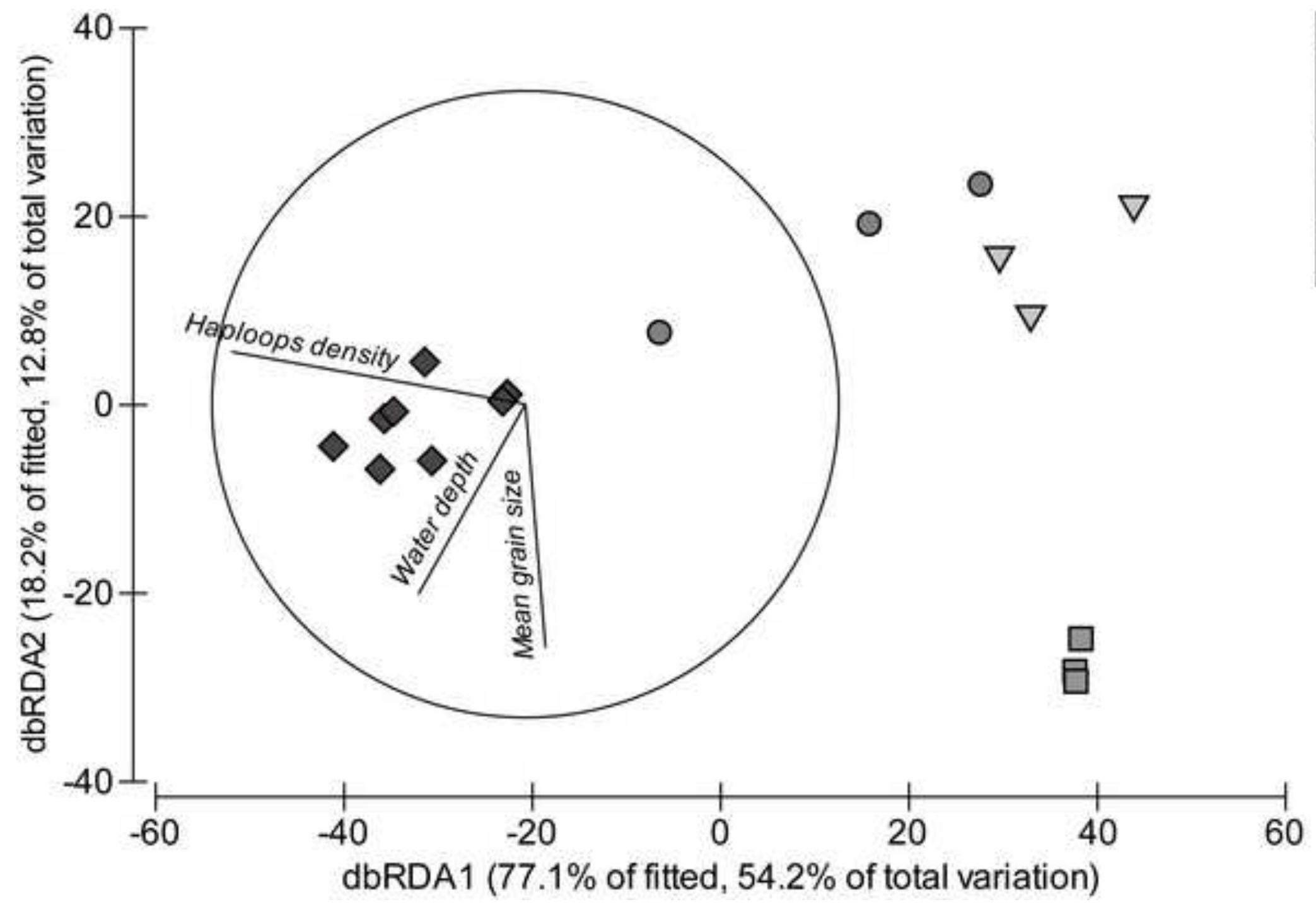

Communities

- Sternaspis

$\nabla$ Amphiura

$\square$ Owenia

$\checkmark$ Haploops 


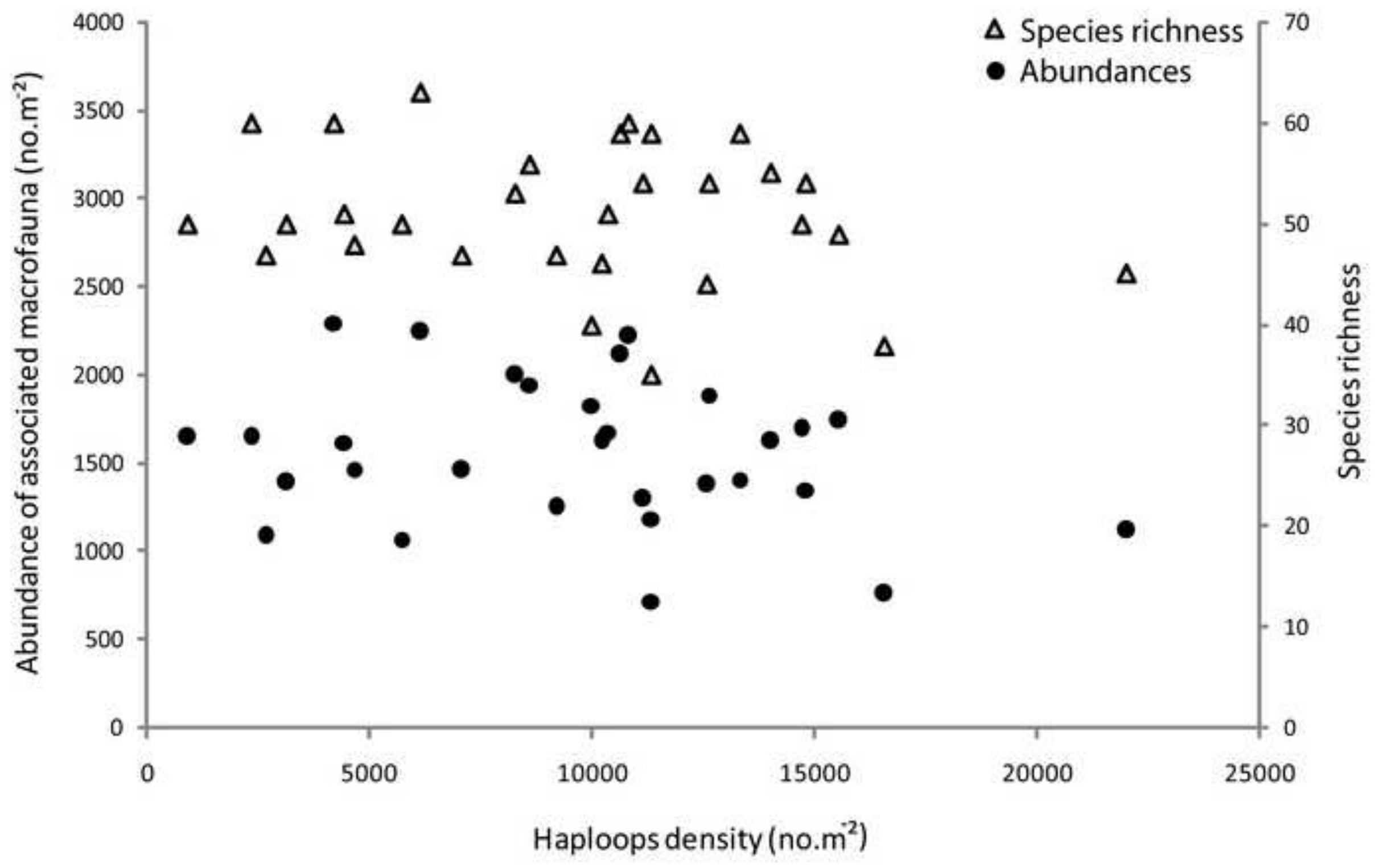



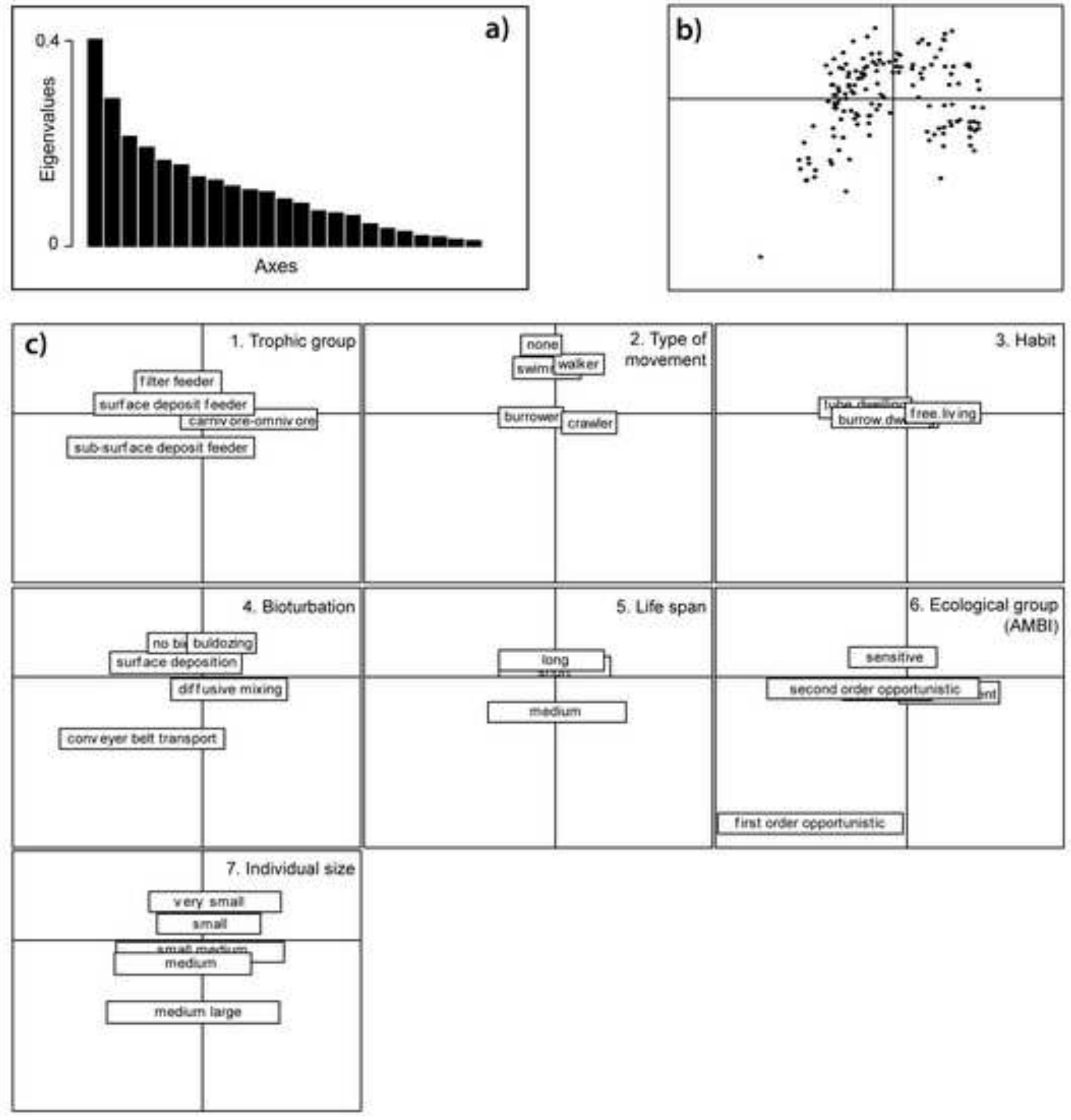
Figure 6
Click here to download high resolution image

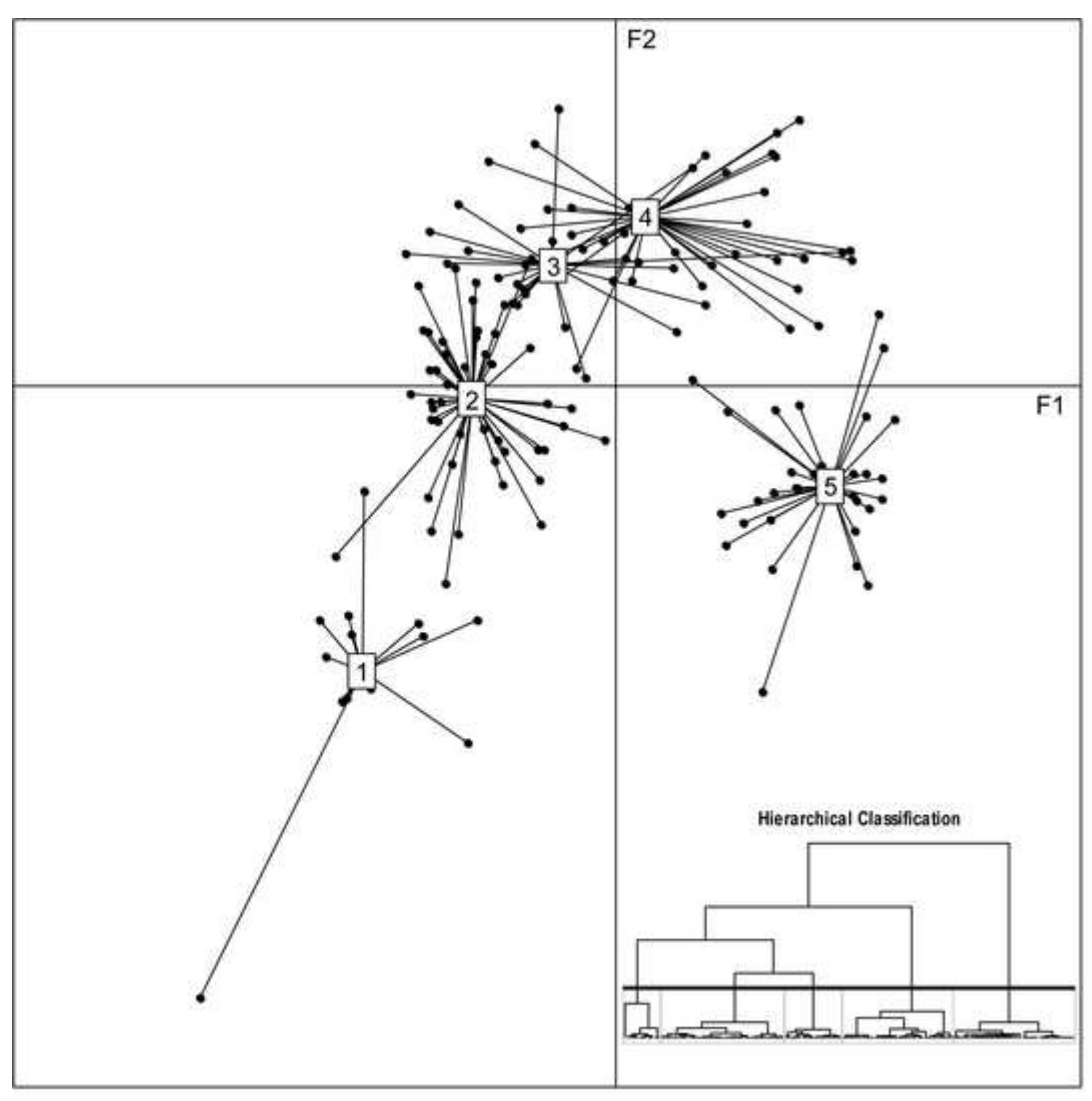


Click here to download high resolution image

1

2

3

4

5
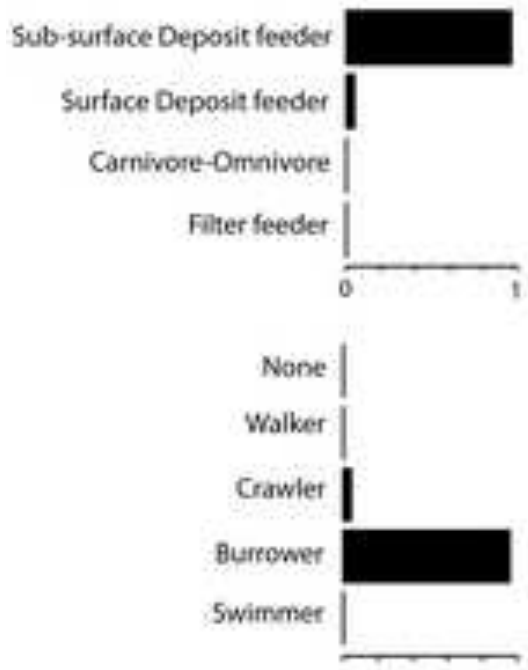

free living

Burrow dwelling

Tube dwelling
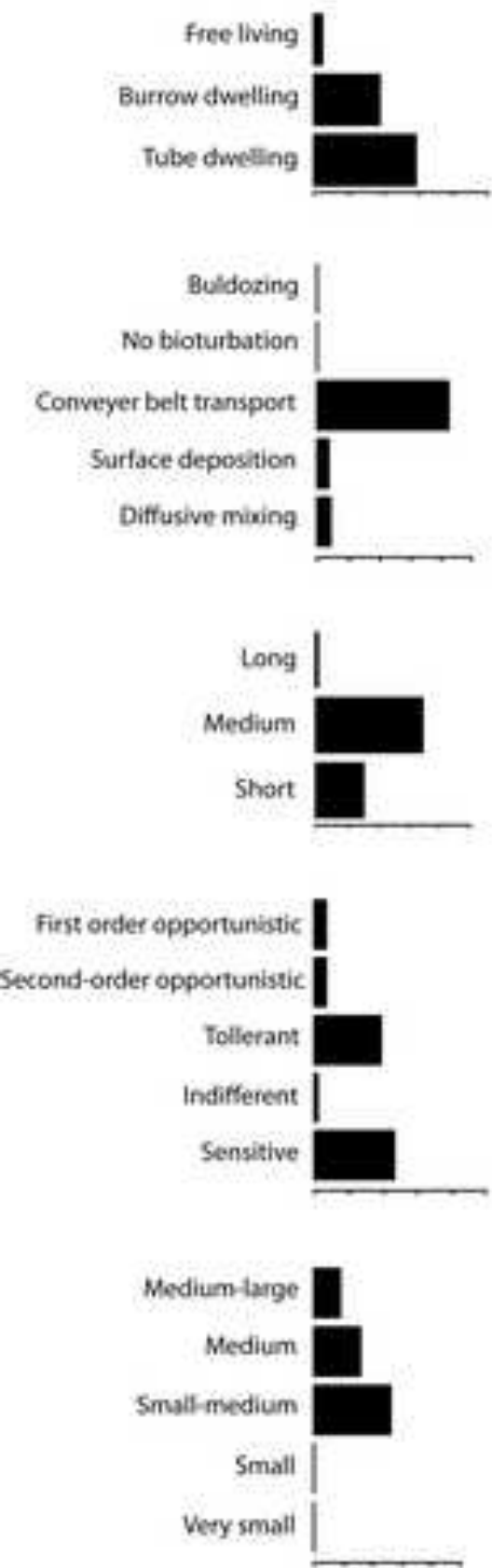
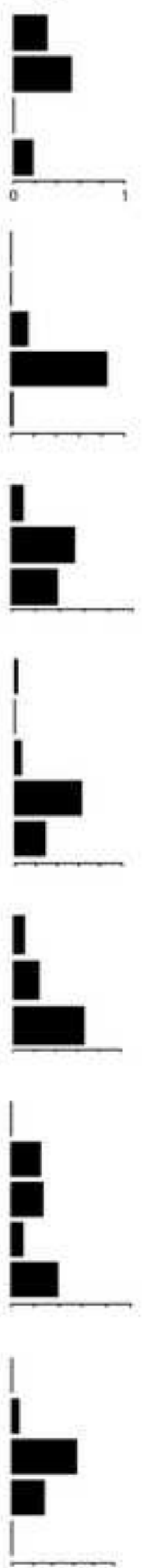
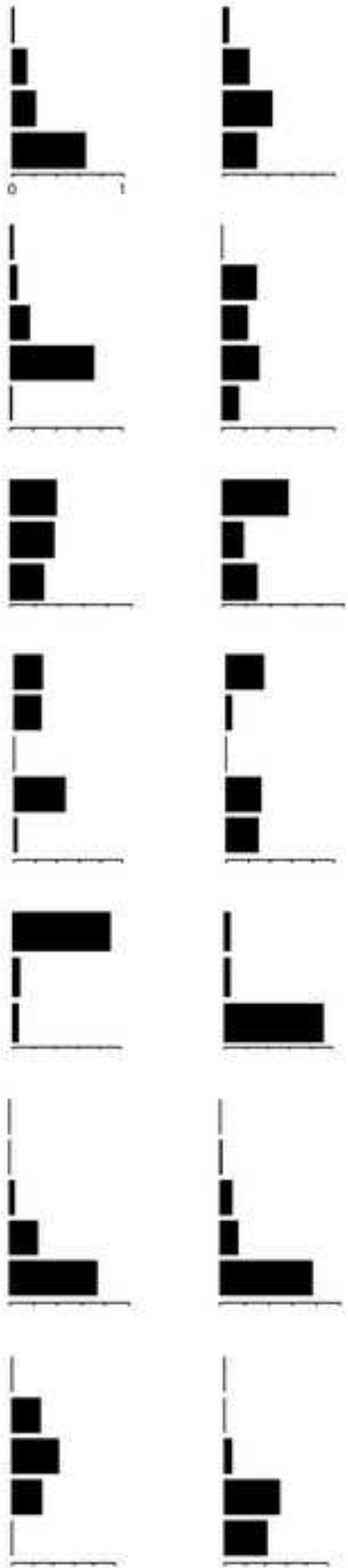
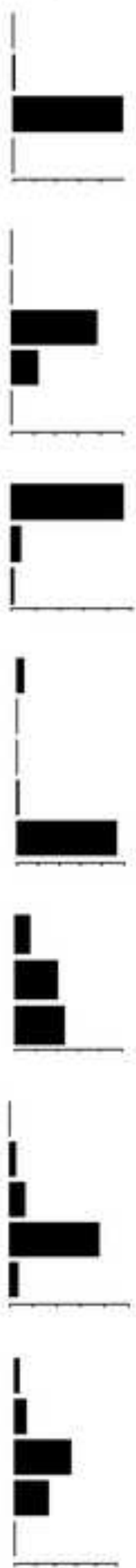


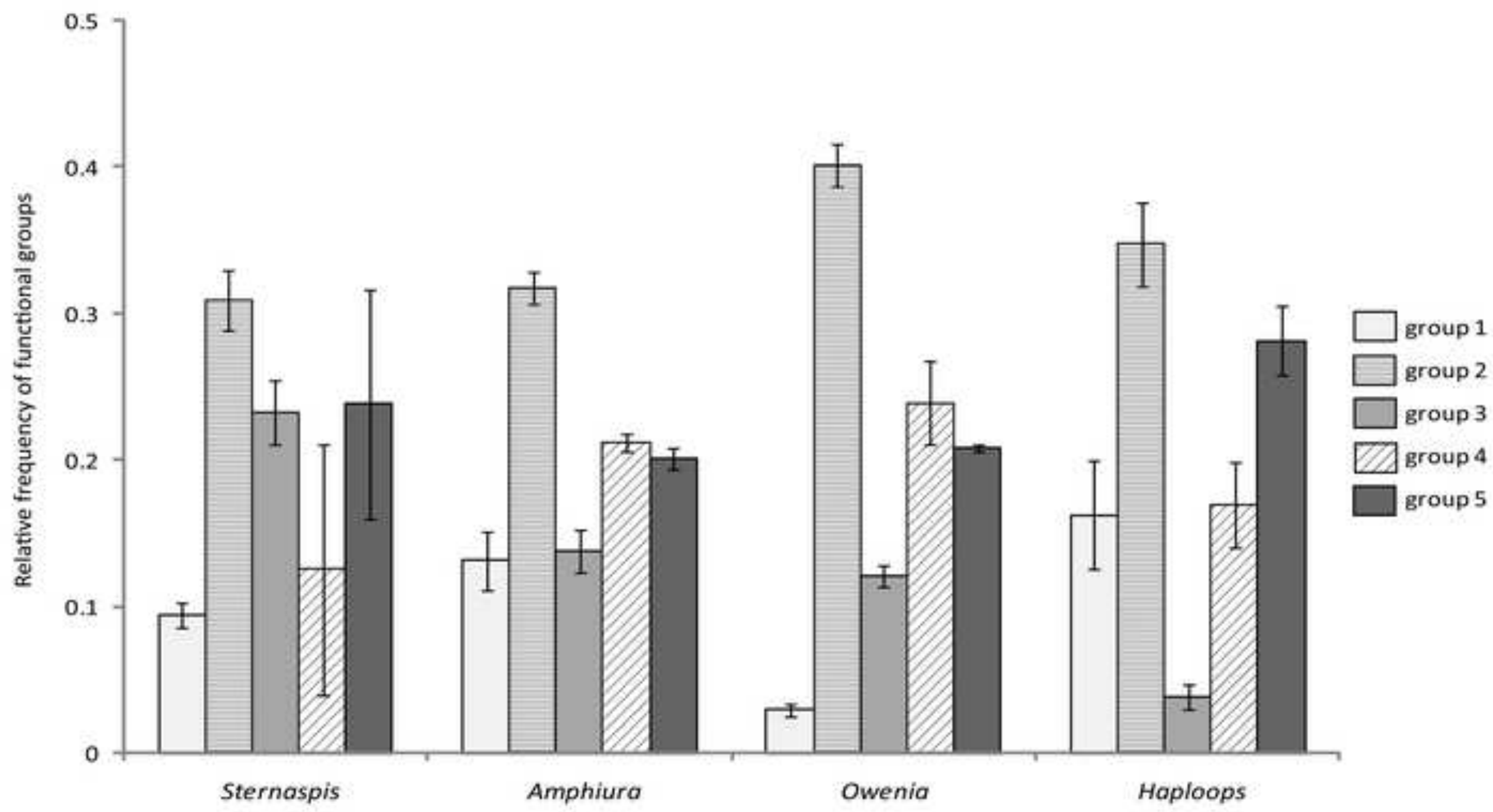


Figure9

Click here to download high resolution image

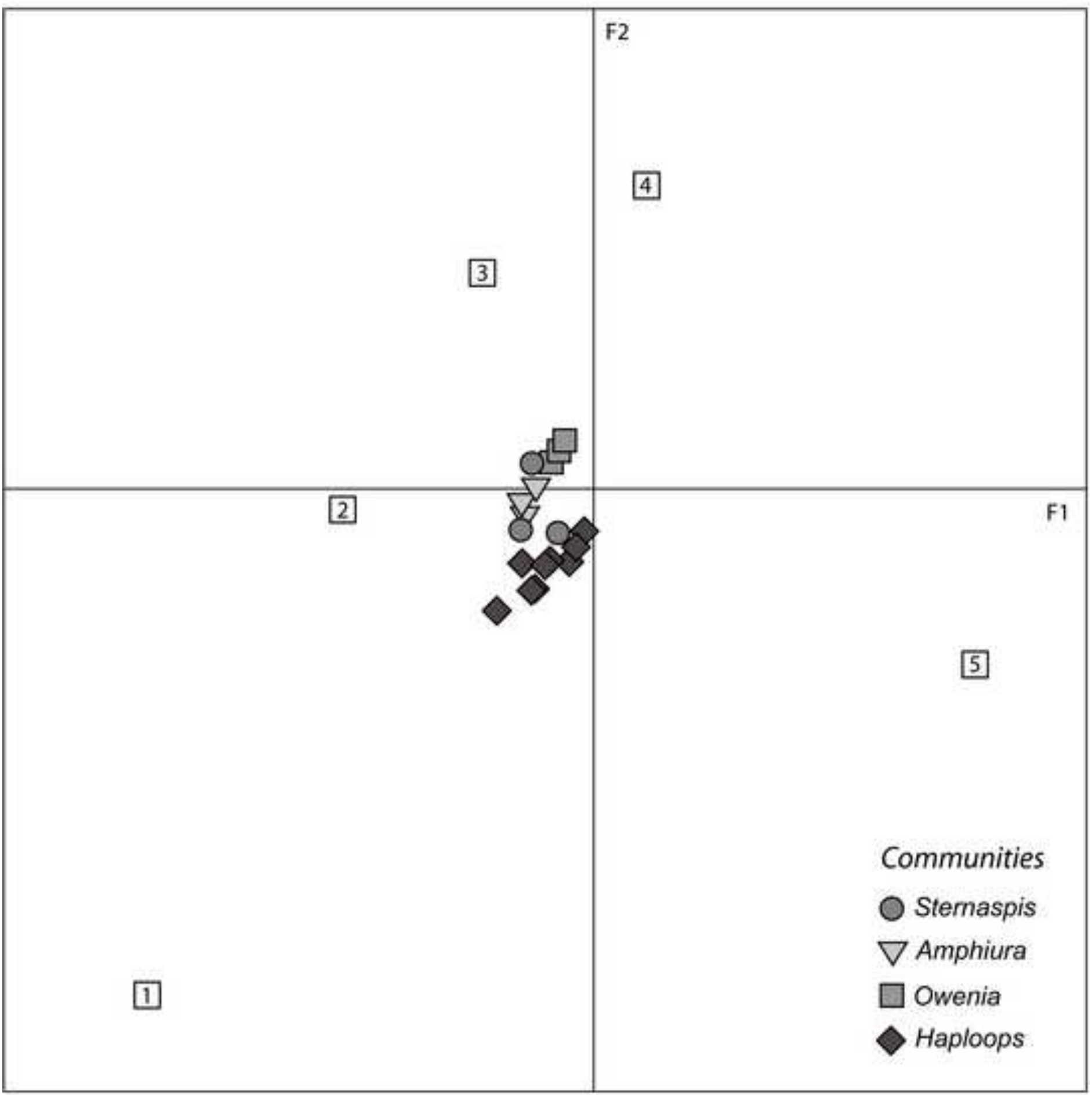

